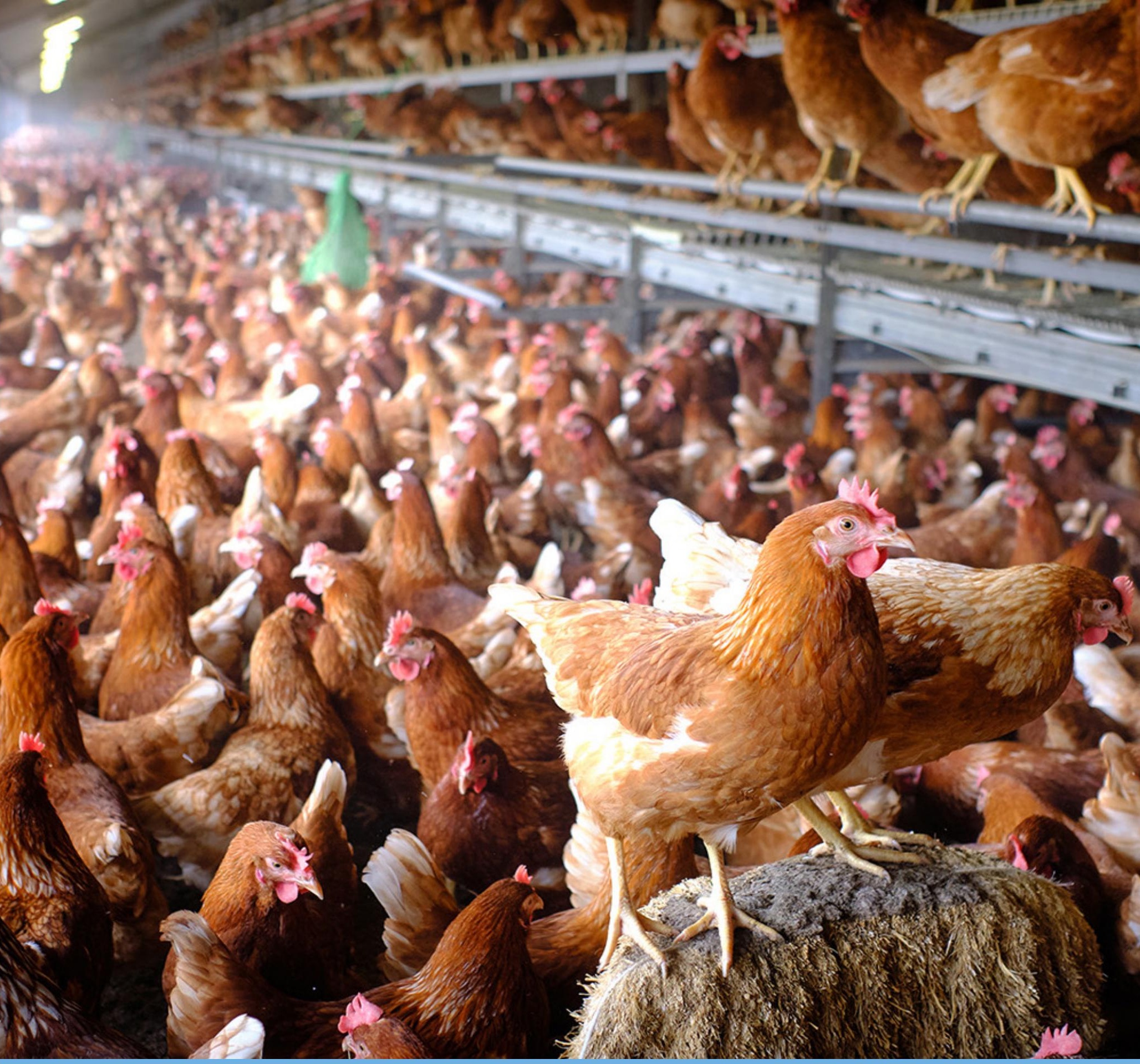

Low crude protein diets supplemented with free amino acids in laying hens

Effects on performance, egg quality, N-efficiency, N-excretion, economics and diet carbon footprint 



\section{Low crude protein diets supplemented with free amino acids in laying hens. Effects on performance, egg quality, N- efficiency, N-excretion, economics and diet carbon footprint}

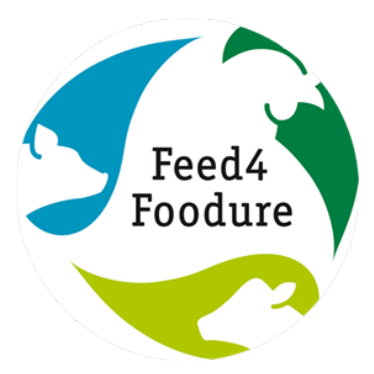

${ }^{1}$ Wageningen Livestock Research

2 De Heus Animal Nutrition B.V. Ho Chi Minh city

${ }^{3}$ De Heus Animal Nutrition

This research was conducted by Wageningen Livestock Research, within the framework of the public private partnership "Feed4Foodure" and partially funded by the Ministry of Agriculture, Nature and Food Quality (Policy Support Research project number BO-31.03-005-00) 
Harn, J. van, A. Rezaei Far, M.M van Krimpen, J. Phuc and C. Veiga, 2021. Low crude protein diets supplemented with free amino acids in laying hens. Effects on performance, egg quality, N-efficiency, $\mathrm{N}$-excretion, economics and diet carbon footprint; Wageningen Livestock Research, Public Report 1343.

\section{Samenvatting NL}

Het verstrekken van voeders aan leghennen met een verlaagd eiwitgehalte aangevuld met vrije aminozuren om in de aminozuurbehoefte van leghennen te voorzien kan bijdragen aan het verminderen van het gebruik van sojaschroot van Zuid Amerikaanse herkomst. In dit rapport worden de resultaten beschreven van een leghennen experiment waarin de effecten van het verstrekken van voeders met een 14, 26 of 41 gram per kilogram verlaagd ruw eiwitgehalte ten opzichte van een controlerantsoen met een eiwitgehalte $161 \mathrm{~g} / \mathrm{kg}$, maar met een vergelijkbaar berekend verteerbaar aminozuurgehalte op de productieresultaten, ei-kwaliteit, N-excretie van leghennen van $39-51$ weken leeftijd.

\section{Summary UK}

Providing laying hens diets with a reduced crude protein (CP) content that are supplemented with free amino acids $(A A)$ to cover the $A A$ requirement might be helpful in reducing the soybean meal content of Latin American origin, and thus in reducing the amount of non-EU protein in the diet. This report describes the results of an experiment in which the effects of low CP diets, with a partial replacement of soybean meal by free AA, on laying performance, egg quality, and $\mathrm{N}$-excretion were evaluated in laying hens from $39-51$ weeks of age.

This report can be downloaded for free at https://doi.org/10.18174/557184 or at www.wur.nl/livestock-research (under Wageningen Livestock Research publications).

\section{(cc) BY-NC}

This work is licensed under a Creative Commons Attribution-Non Commercial 4.0 International License.

(C) Wageningen Livestock Research, part of Stichting Wageningen Research, 2021

The user may reproduce, distribute and share this work and make derivative works from it. Material by third parties which is used in the work and which are subject to intellectual property rights may not be used without prior permission from the relevant third party. The user must attribute the work by stating the name indicated by the author or licensor but may not do this in such a way as to create the impression that the author/licensor endorses the use of the work or the work of the user. The user may not use the work for commercial purposes.

Wageningen Livestock Research accepts no liability for any damage resulting from the use of the results of this study or the application of the advice contained in it.

Wageningen Livestock Research is ISO 9001:2015 certified.

All our research commissions are in line with the Terms and Conditions of the Animal Sciences Group. These are filed with the District Court of Zwolle.

Public Wageningen Livestock Research Report 1343 


\section{Table of content}

Foreword $\quad 5$

$\begin{array}{ll}\text { Summary } & 7\end{array}$

1

$\begin{array}{lr}\text { Introduction } & 9\end{array}$

2

$\begin{array}{ll}\text { Material and Methods } & 10\end{array}$

2.1 Start date and end date of the experiment 10

$\begin{array}{ll}2.2 & \text { Experimental animals } \\ 2.3 & 10\end{array}$

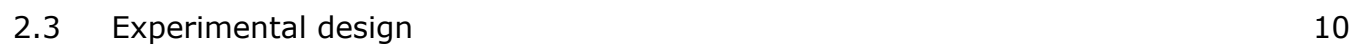

2.4 Experimental diets 11

2.5 Animal and housing $\quad 12$

2.6 Measurements 13

2.6.1 Diet 13

2.6.2 Animal performance parameters 13

$\begin{array}{ll}2.6 .3 \text { Egg quality } & 14\end{array}$

2.6.4 Manure composition $\quad 14$

$\begin{array}{lll}2.7 & \text { Statistics } & 14\end{array}$

$\begin{array}{llr}3 & \text { Results } & 16\end{array}$

3.1 General $\quad 16$

$\begin{array}{lll}3.2 & \text { Diets } & 17\end{array}$

$\begin{array}{lll}3.3 & \text { Laying performance } & 18\end{array}$

$\begin{array}{ll}3.3 .1 \text { General } & 18\end{array}$

$\begin{array}{ll}\text { 3.3.2 Nutrient intake of birds } & 19\end{array}$

$\begin{array}{lll}3.4 & \text { Egg quality } & 21\end{array}$

$\begin{array}{lll}3.5 & \text { Excreta quality } & 22\end{array}$

3.6 Carbon footprint of the diets and economic feed margin as affected by the
dietary treatments

4

$\begin{array}{ll}\text { Discussion } & 25\end{array}$

5 Conclusion $\quad 33$

References $\quad 34$

$\begin{array}{lll}\text { Appendix } 1 & \text { Experimental diets } 1^{\text {st }} \text { batch } & 36\end{array}$

Appendix 2 Experimental diets $2^{\text {nd }}$ batch $\quad 37$

$\begin{array}{lll}\text { Appendix } 3 & \text { Weekly performance parameters } & 38\end{array}$

$\begin{array}{lll}\text { Appendix } 4 & \text { Carbon footprint diets } & 41\end{array}$ 


\section{Foreword}

Feed4Foodure (F4F) is a public-private partnership between the Dutch Ministry of Agriculture, Nature and Food Quality and a consortium of various stakeholders within the animal production chain and Wageningen Livestock Research. Feed4Foodure aims to contribute to sustainable and healthy livestock farming in the Netherlands, simultaneously strengthening its competitive position in the global market. The F4F program line "MVV5", aims to reduce the soybean meal content of Latin American origin, and thus reducing the amount of non-EU protein in the diet of pigs and poultry.

The current report describes the results of an experiment with laying hens in which the effects of low $\mathrm{CP}$ diets, with a partial replacement of soybean meal by free AA, on laying performance, egg quality, $\mathrm{N}$-excretion, feed margin/economics and diet carbon footprint were evaluated.

The experiment was performed at the layer facility of De Heus in Vietnam. The study was designed with input from scientists of Wageningen Livestock Research and representatives of VDN in the F4Fconsortium. The authors thank all members of the project team for their worthwhile input, and the team of the layer facility in Vietnam for performing the experiment.

Jan van Harn, Arya Rezaei Far, Marinus van Krimpen, J. Phuc and Cecile Veiga.

Note: Unfortunately, our dear colleague Marinus passed away suddenly and shortly after completing the work protocol, just before the start of the experiment. His critical input in this project is highly appreciated. 


\section{Summary}

An experiment was conducted with 2880 Bovans Brown layer hens from 39 to 51 weeks of age to evaluate the effects of reducing the crude protein content of iso-energetic diets supplemented with essential amino acids (AA) in free form on laying performance, egg quality, N-excretion, feed margin/economics and carbon footprint.

The experiment was carried at the experimental layer facility of De Heus Vietnam (Vinh Long, Vietnam), and consisted of four dietary treatments differing in crude protein content. Two diets were produced after analysing the major raw ingredients. Diet A with $16.1 \% \mathrm{CP}$ and diet $\mathrm{D}$ with $12.0 \% \mathrm{CP}$. Diet $A$ and $D$ were formulated to meet or exceed the requirements for all commercially available essential AA (Lys, M+C, Thr, Trp, Ile, Arg and Val) and were iso-caloric. Two other treatments were produced by mixing diet $A$ and $D$ in ratios of $65: 35$ (diet $B 14.7 \% C P$ ) and 35:65 (Diet C 13.5\% CP). There were six replicates for each treatment. Each replicate consisted of a row of 20 cages with initially 6 birds in each cage. Laying performance, egg quality characteristics and manure composition (dry matter and nitrogen concentration) were assessed over the experimental period.

Reducing the crude protein content of the diet from $16.1 \%$ to $14.7 \%$ resulted in a higher feed intake and laying rate. Further reduction of the crude protein content to $13.5 \%$ and $12.0 \%$ reduced the feed intake and laying rate. Stepwise reduction of the dietary crude protein content across the treatments, reduced the protein intake, amino acids intake, and egg weight, while FCR increased. Laying hens fed the $12.0 \%$ CP diet had a significantly higher laying rate of 2 nd-grade eggs compared to the other treatments. There was a negative linear relationship between the crude protein content of the diets and the egg weight, and albumen content of eggs. The calculated carbon footprint of the diets linearly increased with the decline of the CP content. The dry matter and nitrogen content of the manure increased when decreasing the crude protein content of the diets, while there was no effect on the ammonium-N content of excreta.

From this study can be concluded that:

- Reduction of the crude protein content of diet from $16.1 \%$ to $14.7 \%$, with similar content of digestible EAA, resulted in a higher laying rate, lower egg weight, and fewer Jumbo eggs. Further reduction of crude protein content to $13.5 \%$ and $12.0 \%$ impaired the laying rate, egg weight, egg mass, and feed efficiency.

- $\quad$ Reducing the crude protein content of the diet from $16.1 \%$ to $14.7 \%$ did not affect the egg mass, but because of the higher feed intake, the FCR increased.

- Reduction in crude protein content of the diets to $13.7 \%$ and $12.0 \%$ CP resulted in impaired laying performance.

- $\quad$ The FCR increased with the decreased crude protein contents of the diets.

- The crude protein content of the diets did not affect the mortality rate.

- The crude protein intake decreased linearly with the reduced crude protein content of the diets.

- $\quad$ Egg weight decreased linearly with decreasing crude protein contents of the diets.

- $\quad$ Feeding diets with $12.0 \% \mathrm{CP}$ increased the laying rate (\%) of second-grade eggs. No differences were observed in the laying rate of the second-grade eggs between the $16.1,14.7$ and $13.5 \%$ diets.

- $\quad$ Albumen in eggs decreased with the decreased crude protein content of the diets.

- Decreasing dietary protein content with similar digestible content of essential amino acids increases the carbon footprint of the diets.

- $\quad$ The calculated feed price increases with a decrease in the crude protein content.

- The calculated economic feed margin is strongly influenced by the availability and price of the protein-rich raw materials and the price of free amino acids. Under the current Dutch market conditions, the feed margins per 100 placed hens of the low-crude protein diets decreased by $€ 12.82$, $€ 56.58$ and $€ 70.08$ respectively for the $14.7,13.5$ and $12.0 \%$ CP-diets.

- The dry matter content of the manure increased linearly with decreasing crude protein content of the diets.

- Total N-content of the manure decreased linearly with decreasing crude protein content of the diets. 
In general, we conclude that lowering the crude protein content of laying hens diets from $16.1 \%$ to $14.7 \%$, by reducing the soybean meal inclusion level and supplementing free essential amino acids , resulted in similar laying performance in laying hens aged between 39 and 51 weeks. Further lowering of the dietary crude protein to $13.5 \%$ and $12.0 \%$ deteriorate performance results. 


\section{Introduction}

The growing world population and the expected increase in prosperity imply that the market demand for animal protein will continue to grow (FAO, 2009; FAO, 2017). It is expected that the demand for poultry meat and eggs will increase rapidly worldwide. As a result, the demand for vegetable proteins, e.g. soybean meal, for use in animal feed will increase (Alexandratos and Bruinsma, 2012). In Europe, the rate of self-sufficiency for soybean meal is only $5 \%$ (EU, 2017). This strong dependency for this important protein source in poultry diets and the low self-sufficiency makes the EU livestock sector vulnerable to price volatility and trade distortions, causing feed price to rise, thereby, increasing farmers' production costs and reducing the sectors' profitability (Euractiv, 2011). Besides, there is concern about the deforestation of tropical rainforest to fulfil the need for arable land for soybean cultivation (WNF, 2011; Van Gelder and Kuepper, 2012).

As a consequence of the transition of natural ecosystems into agriculture, the rate of biodiversity loss (proportion of extinct species) increases, whereas the current status has already more than ten times exceeded the proposed boundary (Rockström et al., 2009). Moreover, large scale soybean cultivation may increase water and soil pollution, and drive small farmers and the native population out of business (WNF, 2011). Among other reasons, this is driving the urge to find alternatives for imported soybean meal in poultry diets. Besides that, the emission of nutrients such as nitrogen and phosphorus via the poultry manure contributes to the environmental impact of the poultry production (Kumari et al., 2016).

A lower inclusion of soybean protein in poultry diets is one way to reduce the use and import of soybeans and soybean meal. This can be done by partial replacing soybean products with other protein commodities such as peas, rapeseed/rapeseed meal, sunflower meal, fish meal, corn gluten meal, and/or potato protein or in the near future novel proteins such as insect protein. Soybean meal has a balanced amino acids pattern that largely meets the amino acid requirements of poultry, and a complete replacement of soybean meal by the aforementioned protein-rich feedstuffs, with a less balanced pattern of amino acids, will increase the use of free amino acids in poultry diets. Partial replacement of soybean meal by free amino acids seems, in view of the economic aspects, to be a more obvious way forward when reducing the use of soybean meal. Reducing the inclusion of soybean meal in amino acids supplemented diets in poultry is in fact in line with the efforts to reduce nitrogen excretion by reducing the crude protein content of diets and optimizing the ideal protein concept.

However, the provision of reduced-crude protein diets may impair growth or egg performance when (semi-) essential amino acids become limiting. To successfully reduce crude protein levels in poultry diets while maintaining performance results, it is essential to keep the supply and the balance of amino acids in line with the bird's requirement. As a result, free amino acids should be adequately supplied to the diet.

A part of the dietary nitrogen intake is not retained by the animal but excreted into the environment. Lowering the crude protein content of the diet could therefore be a tool to reduce the nitrogen excretion and ammonia emission from poultry houses (Roberts et al., 2007). Moreover, low crude protein levels in poultry diets reduce the risk of digestive problems and necrotic enteritis (Palliyeguru et al., 2010). Besides the fact that providing low protein diets to poultry reduces the use of soybean meal, it could also be an efficient tool to improve intestinal health (less digestive disorders and improved health status), animal welfare and to reduce environmental emissions (less $\mathrm{N}$-excretion and ammonia emission) (Qaisrani et al., 2015; Apajalahti and Vienola, 2016).

Within the Feed4Foodure project, several experiments have been performed to assess the effects of low protein diets on broiler growth performance, however, the available knowledge on the effects of low protein diets on the production performance of the laying hens is still limited. The objective of this study was to evaluate the effects of gradual reduction of dietary crude protein from $16.1 \%$ to $12.0 \%$ in amino acids supplemented diets by a partial replacement of soybean meal and sunflower seed meal on laying performance, egg quality, N-efficiency and N-excretion in the laying hens from 39 to 52 weeks of age. In addition, the effects of the diets on feed costs and the carbon footprint were evaluated. 


\section{$2 \quad$ Material and Methods}

\subsection{Start date and end date of the experiment}

Start adaptation period:

End adaptation period:

Start experimental period:

End experimental period:
02 December 2019 (week 37 of age)

15 December 2019 (week 39 of age)

16 December 2019

22 March 2020 (week 52 of age)

\subsection{Experimental animals}

The experiment was carried out with approximately 2880 Bovans Brown laying hens. These hens were housed in eight 3-tier battery cages. In total there were 24 rows, and each row includes 20 cages (5-6 hens/cage). The row was the experimental unit. The experiment started at the age of 37 weeks, with two weeks of adaptation, and completed at the age of 52 weeks.

\subsection{Experimental design}

The experiment was carried out at the experimental layer facility of De Heus Vietnam (Vinh Long, Vietnam). This mechanical ventilated house was equipped with a pad cooling system and a climate computer (Hotraco).

A completely randomized block design was used in this experiment which consisted of four treatments ( $A$ to $D$ ) and four blocks ( 1 to 4 ). The experimental factor was the dietary crude protein content; a control diet (CP 16.1\%) and three other treatments with stepwise reduction of crude protein content (CP $14.7 \%, 13.5 \%, 12.0 \%$ ) by excluding soybean meal from the formulation and decreasing the inclusion level of sunflower meal. By including amino acids, i.e. lysine, methionine, threonine, tryptophan, valine, isoleucine, and arginine in free form, diets were balanced for the digestible concentrations of amino acids.

There were eight 3-tier battery cages in the layer facility. Battery cages formed 4 blocks, with each block consisting of two rows of the 3 -tier battery cages, making in total 8 rows (Figure 1 ). Therefore, there were in total 24 rows each containing 20 cages. A row with 20 cages was considered an experimental unit. There were 5-6 animals per cage. Therefore, each experimental unit included approximately 120 laying hens. Treatments were replicated six times. The distribution of the experimental units in the layer farm is illustrated in Figure 2.

Table 1 Experimental design in summary.

\begin{tabular}{lr} 
Item & Number \\
\hline Treatments & 4 \\
\hline Replicates per treatment & 6 \\
\hline Number of experimental units (one row) & 24 \\
\hline Number of cages in each experimental unit & 20 \\
\hline Number of laying hens in each cage & 6 \\
\hline Total number of laying hens per treatment & 720 \\
\hline
\end{tabular}




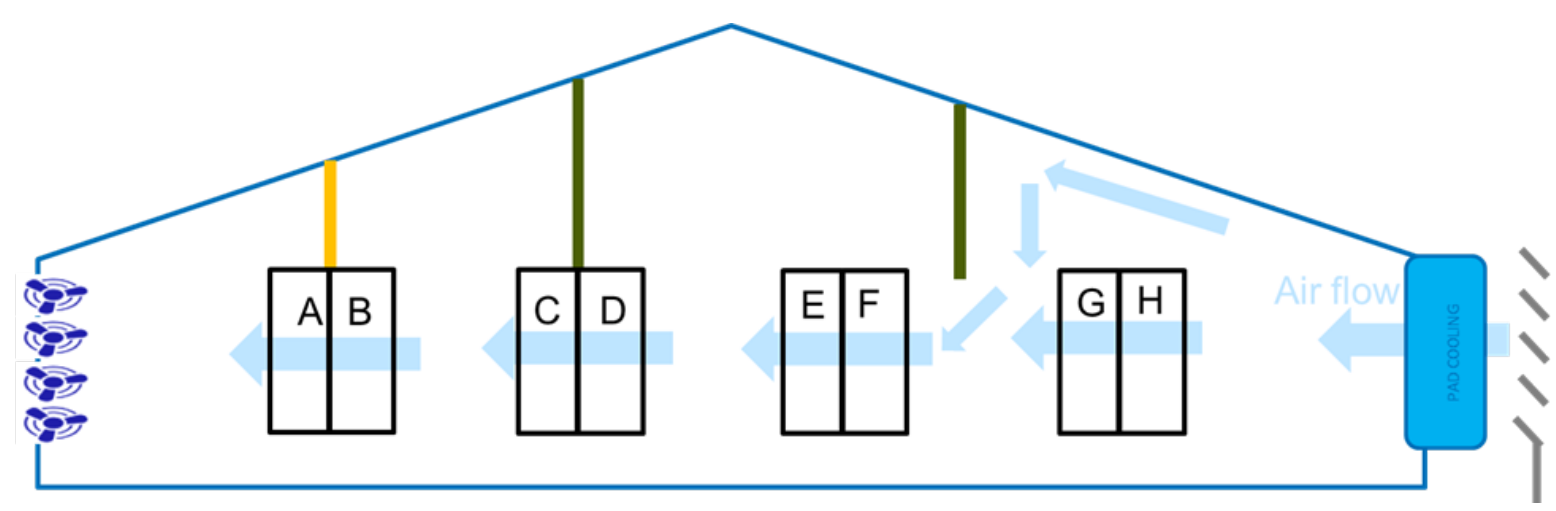

Figure 1 The layer facility was set up in four blocks, with each block consisting of two rows of the 3-tier battery cages, making in total 8 rows (block $1=$ rows $A$ and $B$, block $2=$ rows $C$ and $D$, block $3=$ rows $E$ and $F$ and block $4=$ rows $G$ and $H$ ). Each row consisted of 3 tiers, which counted up to 24 rows in total. One row is an experimental unit.

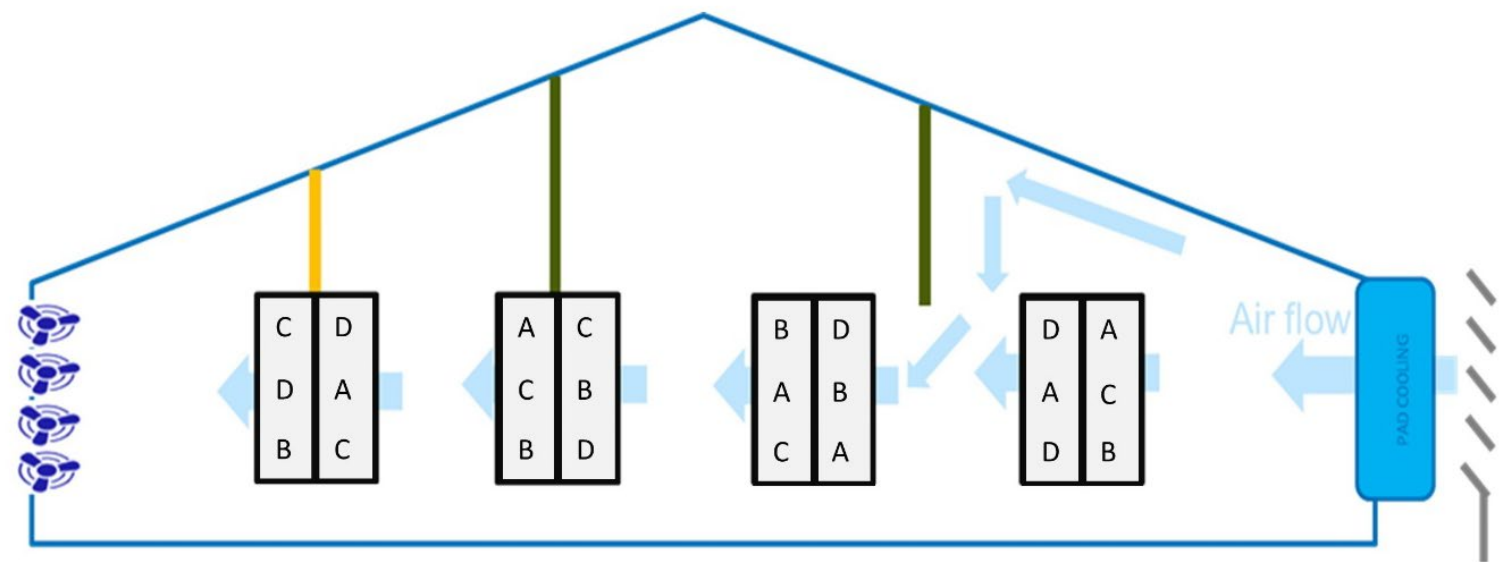

Figure 2 The distribution of treatments ( $A: C P 16.1 \% ; B: C P 14.7 \% ; C: 13.5 \% ; D: 12.0 \%$ ) in the experimental units (row) in the layer farm.

\section{$2.4 \quad$ Experimental diets}

Prior to formulation, the main raw ingredients were analysed by Near-infrared spectroscopy (NIR) to update the ingredient composition matrix in Bestmix. These ingredients included corn, wheat, wheat middling pellets, soybean meal, sunflower meal which were analysed for macronutrients and essential amino acids. After updating Bestmix, RP075 as the control diet (Trt A; CP 16.1\%) and RP078 as the experimental diet with the lowest CP content (Trt D: CP 12\%) were formulated.

Table 2 Experimental treatments. Iso-energetic diets with reduced contents of crude protein being supplemented by available free amino acids ${ }^{1}$.

\begin{tabular}{lll} 
Treatment & Code & Description \\
A & RP075 & Control, CP 16.1\% \\
\hline B & RP076 & Control $-1.4 \%$ CP; diet with $14.7 \%$ CP \\
\hline C & RP077 & Control $-2.6 \%$ CP; diet with $13.5 \%$ CP \\
\hline D & RP078 & Control $-4.0 \%$ CP; diet with $12.0 \%$ CP \\
\hline
\end{tabular}

${ }^{1}$ Lysine, methionine, threonine, valine, arginine, isoleucine, and tryptophan.

Reduction in crude protein in Trt D $(12.0 \% \mathrm{CP})$ was realized by removing the soybean meal and reducing the inclusion level of sunflower meal. The resulting reduction in essential amino acids was compensated by adding free amino acids, i.e. lysine, methionine, threonine, tryptophan, valine, isoleucine and arginine. The other two dietary treatments (Trt B: RP076 and Trt C: RP077) were 
obtained by mixing the control diet (RP075) and the reduced crude protein diet (RP078) in different ratios (Table 3 ).

Table 3 Composing the experimental diets from the low and high protein diet.

\begin{tabular}{|c|c|c|c|c|}
\hline \multirow[b]{2}{*}{ Treatment } & \multicolumn{4}{|c|}{ Mixing } \\
\hline & Code & RP075 & RP078 & Expected CP \% \\
\hline $\mathbf{A}$ & RP075 & $100 \%$ & - & 16.1 \\
\hline B & RP076 & $65 \%$ & $35 \%$ & 14.7 \\
\hline $\mathrm{C}$ & RP077 & $35 \%$ & $65 \%$ & 13.5 \\
\hline D & RP078 & - & $100 \%$ & 12.0 \\
\hline
\end{tabular}

Due to the length of the trial, the experimental diets were produced in two batches on different production dates and with different macro raw materials. All these ingredients were assessed by NIR prior to feed formulation.

- $\quad$ Diets for the first 7 weeks were produced in mid-November 2019 (Appendix 1)

- $\quad$ Diets for the last 8 weeks were produced begin January 2020 (Appendix 2)

In total, four iso-energetic experimental diets with the same digestible lysine content $(0.69 \%)$ were produced to meet or exceed the requirements for commercially available essential AA (Lys, M+C, Thr, Trp, Ile, Arg and Val), metabolizable energy (2800 kcal/kg ME Lay), calcium, digestible phosphorus and minerals recommended by CVB (2018) for laying hens. All diets were produced and pelleted (4.0 $\mathrm{mm}$ ) on the commercial line and crumbled afterwards at the Dong Nai factory, Vietnam.

\subsection{Animal and housing}

The experiment started with a total number of approximately 2880 Bovans Brown laying hens at the age of 37 weeks. The laying house was equipped with battery cages and a pad cooling system on one side and the exhausting fans on the other side. The pad cooling and exhaust fans were controlled by a Hotraco climate computer to maintain the indoor climate settings. The indoor target temperature was set at $25^{\circ} \mathrm{C}$. The sum of temperature and relative humidity, as a parameter for the prevailing climate conditions in the facility, was allowed to be a maximum of 115 . On the occasion that this level was reached ventilation rate was increased gradually. The pad cooling was set on when maximum ventilation alone could not maintain the target temperature. Curtains were hung vertically from the roof to the top of the tier battery cages to maximize air speed through the cages. After fully closing the curtains, the airflow was between 1.1 to $1.6 \mathrm{~m} / \mathrm{s}$.

The experiment started with an adaptation period of two weeks, followed by an experimental period of 13 weeks. The age of the hens at the end of the experimental period was 52 weeks. During the adaptation period and the experimental period, the experimental diets were provided. The housing, management, feeding and husbandry conditions were standard and representative for commercial layer operations with battery cages. Water was provided ad libitum and feed was distributed three times a day: $9-11 \mathrm{~h}, 13-14 \mathrm{~h}$, and $16-17 \mathrm{~h}$ manually via feeding trolleys above the cages. The feed gift provided was based on the number of hens per row. The lighting program was the same during the entire experimental period; 16 hours light (from $4 \mathrm{~h}$ to $20 \mathrm{~h}$ ) and 8 hours dark per $24 \mathrm{~h}$. Light intensity was the highest in the lower tier (46 Lux), while it was slightly less in the middle and upper tiers (37 and 46 Lux, respectively). The variation in light density was taken into account in the statistical analysis and randomization.

Visual observation of the birds was done twice per day to check animal health. Infectious Bronchitis and Newcastle Disease vaccines were given every six weeks via the drinking water. 

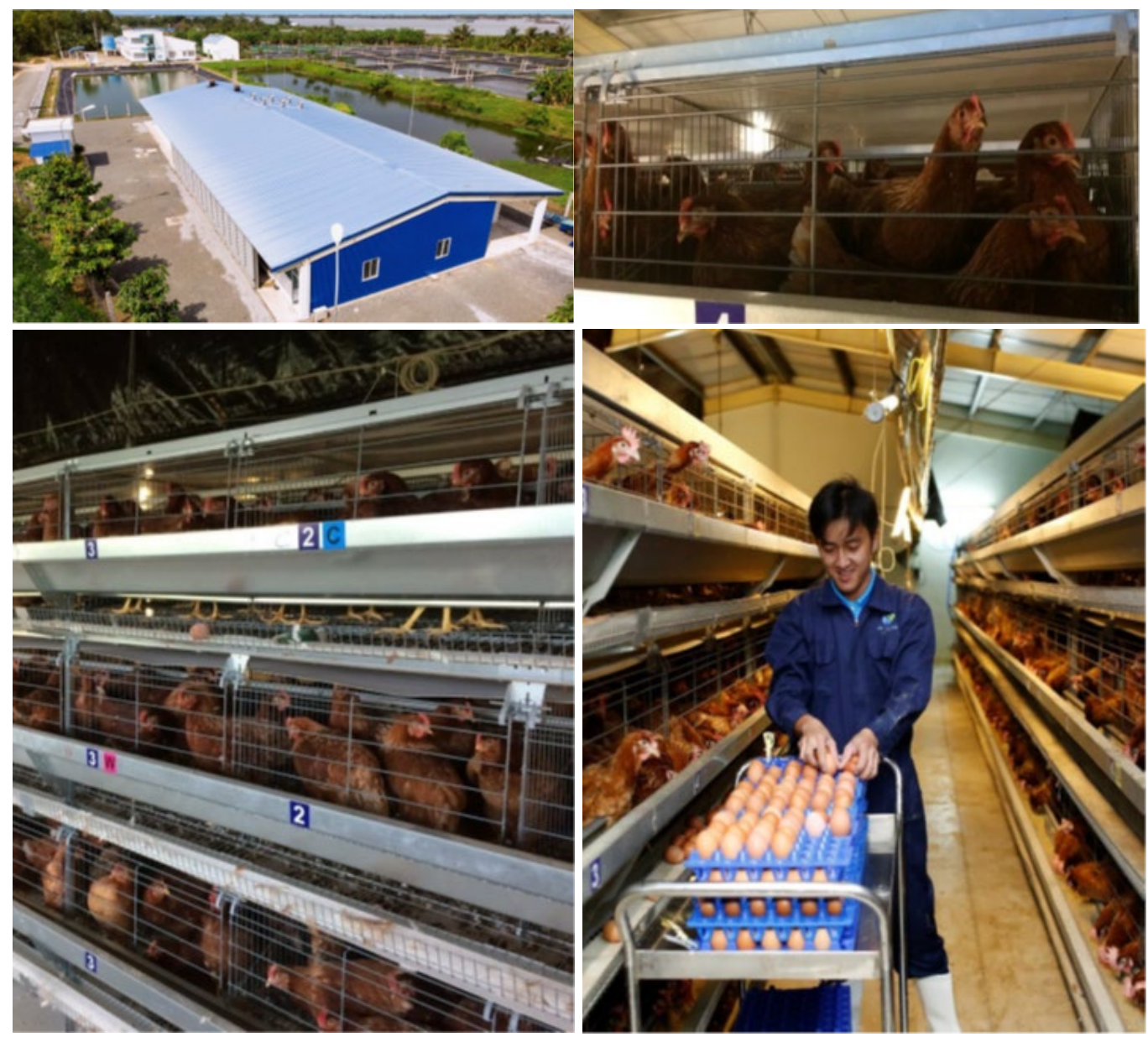

Figure 3 Top left: Laying hen facility Vinh Long, Vietnam; Top right: one cage hosting initially 6 laying hens; Bottom left and right: 3-tiers battery cages. Each tier including 20 cages formed a row (an experimental unit).

\subsection{Measurements}

\subsubsection{Diet}

After pelleting, and just before bagging, each diet was sampled. These samples were pooled to form a composite, representative sample of each diet. All diets ( 2 batches of the four dietary treatments) were analysed on contents of dry matter, crude protein, crude fat, crude fibre, ash, starch, sodium, chlorine, manganese, magnesium, copper, zinc, and total amino acids content. All proximate analyses were performed by wet chemical analyses and NIR. The amino acid analyses were performed by Eurofins, Ho Chi Minh City, Vietnam (first batch of diets) and Evonik, Singapore (second batch of diets) (EC No 152/2009). In addition, dry sieve analysis and pellet durability index were assessed.

\subsubsection{Animal performance parameters}

The body weight (BW) of birds was assessed every two weeks by measuring the mean body weight of hens in four marked cages per experimental unit. Feed intake (FI) was measured for each experimental unit, weekly. Regarding the production performance, laying rate (\%), egg weight (g), mortality $(\%)$, egg mass (EM= egg weight in $\mathrm{g} \times$ laying rate in \%) and feed conversion ratio (FCR= feed intake/egg mass) were recorded in each experimental unit on a weekly basis. The amount of $2^{\text {nd }}$ grade eggs was recorded visually every day. The $2^{\text {nd }}$-grade eggs were considered unsellable eggs, i.e. eggs with shell defects, abnormal size (tiny or double yolked), eggs with (blood)stains, and broken eggs. 


\subsubsection{Egg quality}

Characteristics of the eggs produced in a day were measured individually, every two weeks (between 38 to $46 \mathrm{wks}$ ) and then in a weekly manner (from 46 to $52 \mathrm{wks}$ ). These characteristics included egg weight, breaking strength of the eggshell (BS; Futura device), egg composition ( $g$; the amount of yolk, albumen and eggshell), Haugh unit and thickness of the shell in three points ( $\mu \mathrm{m}$; top, equator, bottom). The percentage of eggs in each experimental unit with $\mathrm{BS}<25 \mathrm{~N}$ was calculated based on the BS values.

Fifteen eggs from each row (= experimental unit) were selected with a weight of $+/-0.4 \mathrm{~g}$ of the mean egg weight of the row and the egg component and Hauge unit were measured. The eggshell thickness of three eggs per row was measured on 3 points (top, equator, bottom) by the means of a micrometre with $0.001 \mathrm{~mm}$ accuracy (Helios-Preisser, DE).

Table 4 The measurement of individual egg characteristics during the experimental period (39 52 weeks).

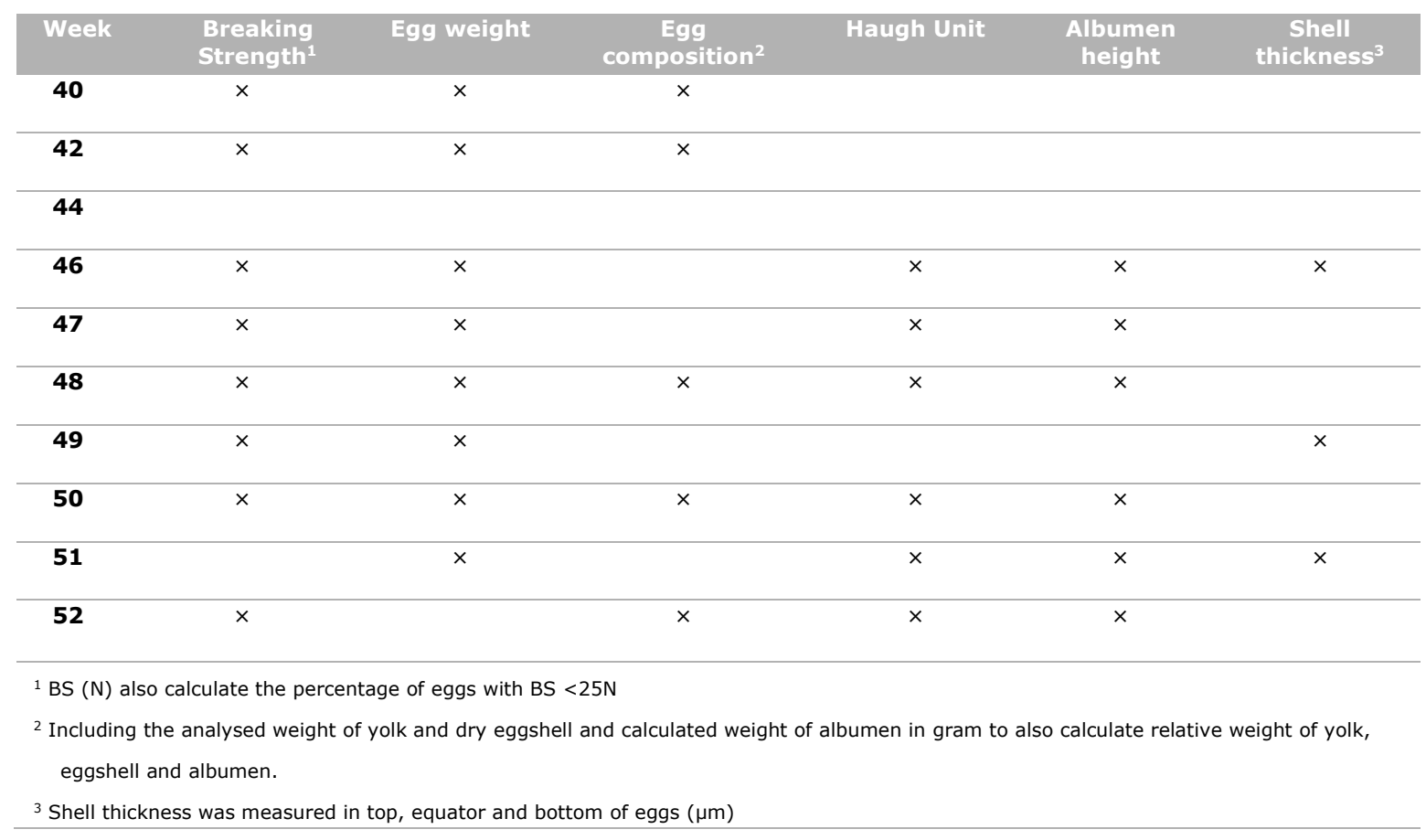

\subsubsection{Manure composition}

Representative samples from each experimental unit were taken to assess the dry matter, total nitrogen and $\mathrm{NH}_{3}-\mathrm{N}$ content (UPScience, $\mathrm{VN}$ ) as the manure quality indicators, in weeks $40,41,45$ and 51.

\section{$2.7 \quad$ Statistics}

Raw data were analysed for statistical outliers. An outlier was defined as an observation which is deviating more than 2.5 standard deviations from the mean. If the deviation of observation was more than 2.5 times the standard deviation from the mean and there was a plausible reason for this deviation, the observation was excluded from the dataset. The experimental data were analysed using GenStat statistical software (GenStat ${ }^{\mathrm{TM}}$ Release 19.1) on Windows 7.

The P-value of the treatment effect and the LSD (least significant difference $(P=0.05)$ ) were provided per response parameter. Treatment effects with a P-value $<0.05$ were considered to be statistically significant. 
Response parameters were analysed using ANOVA (analysis of variance) according to the following model:

$Y_{i j k}=\mu+$ Age $_{i}+$ Treatment $_{j}+$ Week/Position $_{k}+e_{i j k}$

In which:
$\mathrm{Y} \quad$ = dependent variable,
$\mathrm{M} \quad$ = overall mean
Age $\quad=$ (fixed effect): age of the layers in weeks
Treatment $\quad=$ (fixed effect): treatment (crude protein) effect, $n=4$
Week/Location $=($ random term): Week and Position (Height+Row) with height within position being the block
e
$=$ residual error 


\section{Results}

\subsection{General}

Due to a defect of one of the temperature sensors in the barn, the results obtained in week 5 (41 weeks of age) of the experiment had to be excluded from the statistical analysis. The barn was equipped with four temperature sensors. The sensor located close to the pad cooling was defect and overestimated the actual temperature. As a result, the pad cooling system worked excessively to reach the target temperature and the air temperature in the cages close to the pad cooling system decreased, resulting in increased feed intake in these cages in week 5 . Due to this, the results obtained at week 5 of the experiment had to be excluded from the statistical analysis.

In week 15 of the experiment (52 weeks of age), an error was made in the recording of the supply of the diets. As a result, the obtained performance data in this period were not reliable and the performance results obtained in week 15 of the experiment had to be excluded from the statistical analysis.
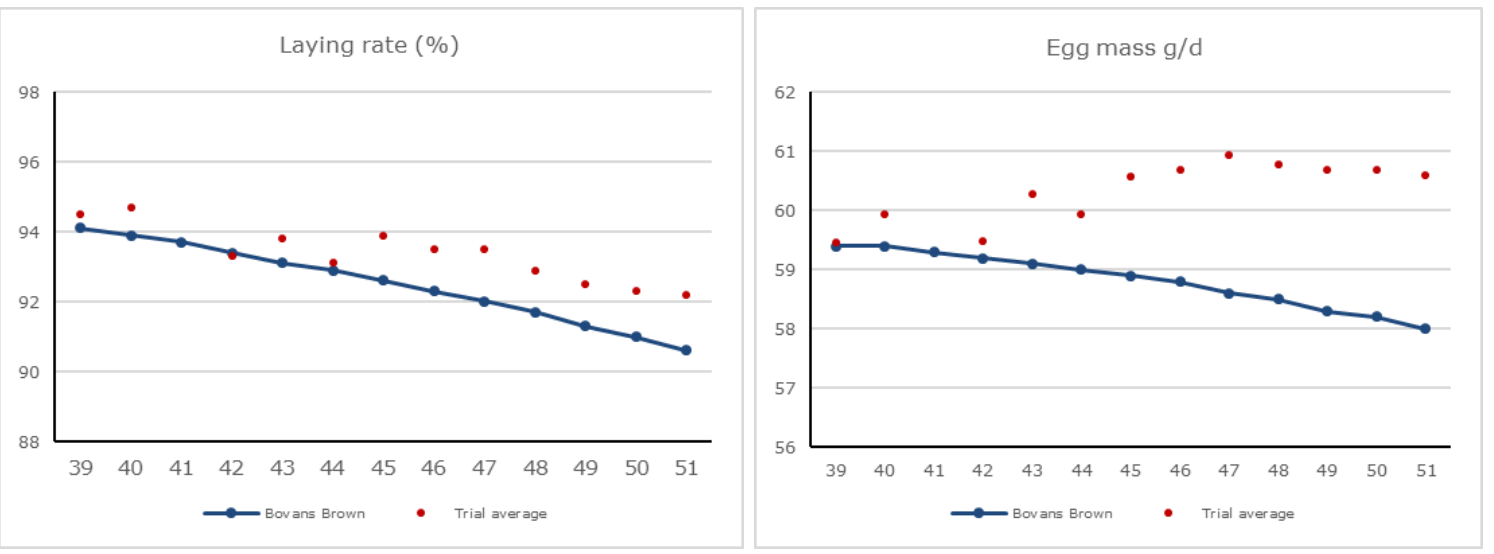

Figure 4 Average laying rate (left) and egg mass (right) of birds in the present experiment compared with Bovans Brown laying performance objectives for the cage-housed hens (Hendrix Genetics, 2021).
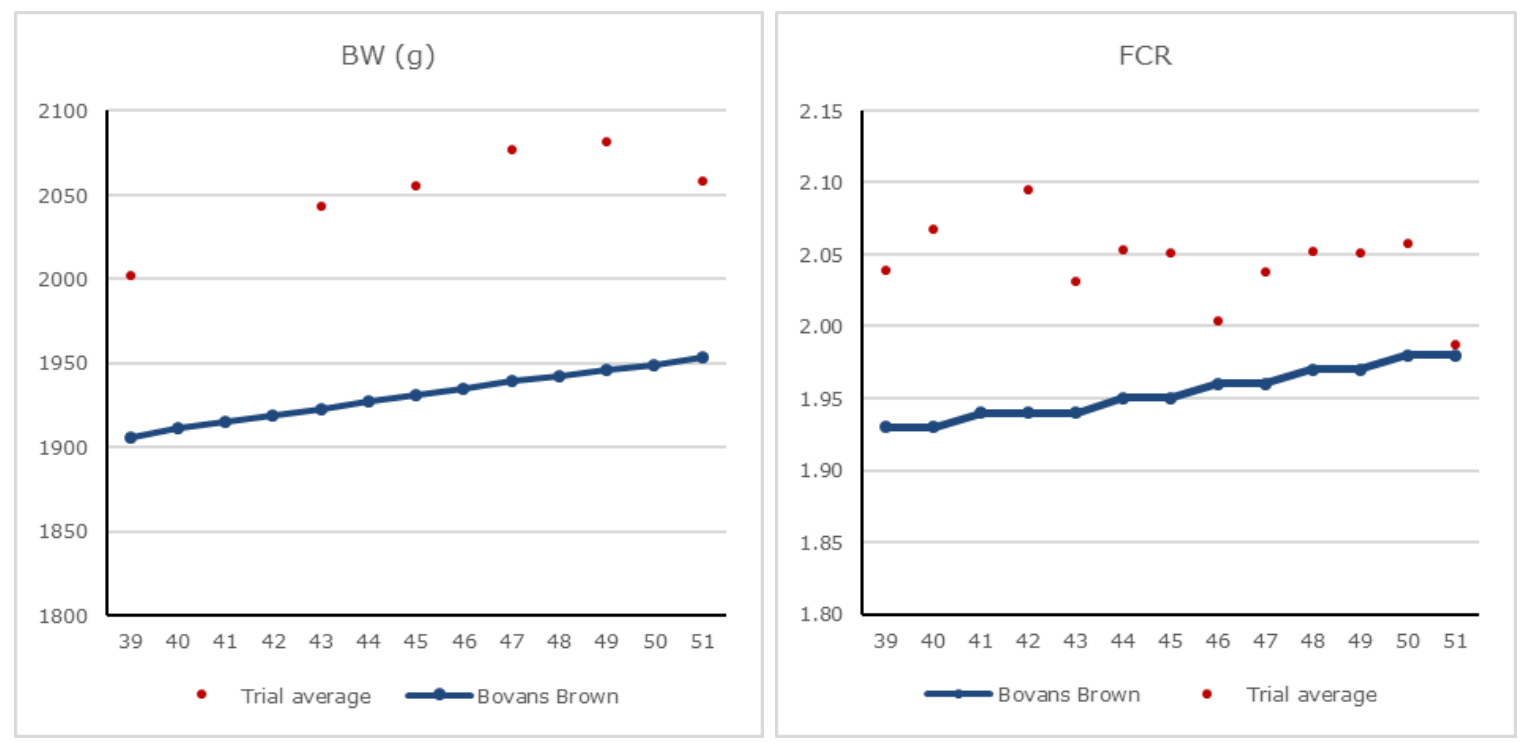

Figure 5 Average body weight (left) and feed conversion ratio (right) of birds in the present experiment compared with Bovans Brown laying performance objectives for cage-housed hens (Hendrix Genetics, 2021). 
Figures 4 and 5 illustrate the average laying performance in this experiment in comparison to the performance objectives of Bovans Brown (Hendrix Genetics, 2021). In general, the average performance of the treatments in this trial was higher than the performance objective of Bovans Browns in cages (ISA, 2021). Despite the fluctuations over the first eight weeks of the experiment (39-44 wks), the laying performance showed the same trend as the standard of Bovans Brown. The bodyweight of the laying hens was from the beginning of the experiment higher than the Bovans Brown performance objectives. The higher average laying rate and egg weight in this experiment resulted in a greater egg mass ( $\mathrm{g} /$ day) than the objectives of Bovans Brown over the experimental period. The average feed intake of each week was higher than the objectives of Bovans Brown and resulted in a higher feed conversion ratio.

The cumulative mortality between weeks 39 to 51 was $4.0 \%$, which is higher than normal in this facility $(0.9 \%)$ and also higher than the expected cumulative mortality of Bovans Brown, kept in cages under (sub) tropical circumstances. However, the crude protein content of the diet did not affect the cumulative mortality of birds during the study (see 3.3.1).

\subsection{Diets}

In Table 5, the calculated and analysed nutrient contents of the experimental diets are given. Regarding the crude protein content, the variations between the two batches of each treatment and deviations from the calculated content were small (from -1 to $4 \%$ relative difference). In general, the analysed nutrient content of crude protein and crude fat was in line with the calculated content.

Deviations in total phosphorus content between calculated and analysed contents were observed among treatments (between -2 to $13 \%$ ). Average P-content in diets A, B and D was slightly higher than calculated ( $5-6 \%$ ), whereas the P-content diet $C$ was on average $5 \%$ lower. In particular, the analysed total phosphorus content of the second batch of diet $D$ was $0.6 \mathrm{~g} / \mathrm{kg}$ higher than the calculated value ( $5.4 \mathrm{vs} 4.8 \mathrm{~g} / \mathrm{kg}$ ), which resulted on average (both batches) in a $6 \%$ higher total phosphorus content in the diet (5.1 vs $4.8 \mathrm{~g} / \mathrm{kg})$.

Table $5 \quad$ Analysed and calculated ${ }^{1}$ nutrient contents $(\mathrm{g} / \mathrm{kg})$ in the experimental diets.

\begin{tabular}{|c|c|c|c|c|c|c|c|c|c|c|c|c|c|c|c|}
\hline & & \multirow{2}{*}{\multicolumn{2}{|c|}{$\begin{array}{l}\text { Moisture } \\
\mathrm{g} / \mathrm{kg}\end{array}$}} & \multirow{2}{*}{\multicolumn{2}{|c|}{$\begin{array}{c}\text { Crude } \\
\text { protein } \\
\mathrm{g} / \mathrm{kg}\end{array}$}} & \multirow{2}{*}{\multicolumn{2}{|c|}{$\begin{array}{l}\text { Crude fat } \\
\qquad \mathrm{g} / \mathrm{kg}\end{array}$}} & \multirow{2}{*}{\multicolumn{2}{|c|}{$\begin{array}{l}\text { Crude } \\
\text { fibre } \\
\mathrm{g} / \mathrm{kg}\end{array}$}} & \multirow{2}{*}{\multicolumn{2}{|c|}{$\begin{array}{c}\text { Crude ash } \\
\qquad \mathrm{g} / \mathrm{kg}\end{array}$}} & \multirow{2}{*}{\multicolumn{2}{|c|}{$\begin{array}{l}\text { Calcium } \\
\text { g/kg }\end{array}$}} & \multirow{2}{*}{\multicolumn{2}{|c|}{$\begin{array}{c}\text { Phosphorus } \\
\text { g/kg }\end{array}$}} \\
\hline & & & & & & & & & & & & & & & \\
\hline \multirow[t]{3}{*}{$A$} & Batch 1 & 97 & & 164 & & 27 & & 38 & & 120 & & 35 & & 4.9 & \\
\hline & Batch 2 & 100 & & 160 & & 26 & & 41 & & 114 & & 35 & & 5.1 & \\
\hline & Average & 99 & (98) & 162 & (161) & 26 & (25) & 39 & (44) & 117 & (121) & 35 & (36) & 5.0 & $(4.7)$ \\
\hline \multirow[t]{3}{*}{ B } & Batch 1 & 100 & & 151 & & 27 & & 34 & & 126 & & 37 & & 4.9 & \\
\hline & Batch 2 & 97 & & 146 & & 26 & & 39 & & 127 & & 42 & & 4.9 & \\
\hline & Average & 98 & (99) & 148 & (147) & 26 & (26) & 37 & $(42)$ & 126 & (121) & 39 & (36) & 4.9 & $(4.7)$ \\
\hline \multirow[t]{3}{*}{$C$} & Batch 1 & 101 & & 134 & & 27 & & 34 & & 110 & & 32 & & 4.5 & \\
\hline & Batch 2 & 101 & & 138 & & 28 & & 31 & & 113 & & 36 & & 4.6 & \\
\hline & Average & 101 & $(100)$ & 136 & (135) & 27 & (26) & 33 & $(40)$ & 112 & $(120)$ & 34 & (36) & 4.6 & $(4.8)$ \\
\hline \multirow[t]{3}{*}{$D$} & Batch 1 & 97 & & 125 & & 29 & & 36 & & 108 & & 31 & & 4.7 & \\
\hline & Batch 2 & 104 & & 125 & & 30 & & 30 & & 106 & & 34 & & 5.4 & \\
\hline & Average & 100 & $(100)$ & 125 & (120) & 29 & (26) & 33 & (38) & 107 & (120) & 32 & (36) & 5.1 & $(4.8)$ \\
\hline
\end{tabular}

${ }^{1}$ Calculated values are given between brackets

The calcium content of treatment $B$ was the highest and treatment $D$ the lowest across the treatments. The average calcium content of treatment B was $8 \%$ higher and treatment D was $11 \%$ lower than the calculated values. The trend in calcium content was in line with ash content. In a similar way, the ash content in the experimental diet of treatment B was $4 \%$ higher and in treatment D $11 \%$ higher than the calculated values. Crude ash in all diets was lower than calculated (on average $14 \%$ ). Simultaneous deviations in the total phosphorus and calcium content varied the Ca to $\mathrm{P}$ ratio 
from the calculated value (7.5-7.6) among the treatments. In the case of dietary treatment $D$, the ratio was between 6.3 and 6.6 .

Table 6 illustrates the analysed content of the total amino acids in the experimental diets as analysed by Eurofins (first batch) and Evonik (second batch) (EC No 152/2009). In general, the deviations in analysed amino acids concentrations from the calculated values were considered relatively small and acceptable and were in line with the experimental set-up, except for diet C. All analysed major limiting/essential amino acids of this diet were lower than calculated. The deviation (relative difference) between the analysed and calculated values for Lys, M+C, Thr, Val, Arg and Ile was -4, $10,-8,-4,-6$ and $-7 \%$, respectively.

Table 6 Analysed content of amino acids $(\mathrm{g} / \mathrm{kg})$ in the two batches of the experimental diets.

\begin{tabular}{|c|c|c|c|c|c|c|c|c|c|c|c|c|c|c|c|}
\hline & & \multirow{2}{*}{\multicolumn{2}{|c|}{$\begin{array}{c}\text { Lysine } \\
\text { g/kg }\end{array}$}} & \multicolumn{2}{|c|}{ Methionine } & \multicolumn{2}{|c|}{$M+C$} & \multicolumn{2}{|c|}{ Threonine } & \multicolumn{2}{|c|}{ Valine } & \multicolumn{2}{|c|}{ Arginine } & \multicolumn{2}{|c|}{ Isoleucine } \\
\hline & & & & & / kg & & $/ \mathrm{kg}$ & & $/ \mathrm{kg}$ & & $/ \mathrm{kg}$ & & kg & & $/ \mathrm{kg}$ \\
\hline \multirow[t]{3}{*}{ A } & Batch 1 & 8.0 & & 4.0 & & 7.0 & & 6.3 & & 7.4 & & 10.3 & & 6.2 & \\
\hline & Batch 2 & 7.8 & & 3.6 & & 6.4 & & 5.6 & & 7.4 & & 9.7 & & 6.4 & \\
\hline & Average & 7.9 & (7.9) & 3.8 & (3.9) & 6.7 & (6.9) & 6.0 & $(5.8)$ & 7.4 & $(7.4)$ & 10.0 & $(10.3)$ & 6.3 & $(6.2)$ \\
\hline \multirow[t]{3}{*}{ B } & Batch 1 & 8.3 & & 4.1 & & 6.7 & & 6.1 & & 7.6 & & 9.8 & & 6.2 & \\
\hline & Batch 2 & 8.0 & & 3.8 & & 6.3 & & 5.4 & & 7.1 & & 9.2 & & 6.1 & \\
\hline & Average & 8.2 & $(7.8)$ & 4.0 & $(4.1)$ & 6.5 & (6.9) & 5.8 & (5.7) & 7.4 & $(7.2)$ & 9.5 & $(9.6)$ & 6.2 & (6.1) \\
\hline \multirow[t]{3}{*}{ C } & Batch 1 & 7.7 & & 3.9 & & 6.4 & & 5.4 & & 6.9 & & 8.6 & & 5.7 & \\
\hline & Batch 2 & 7.1 & & 3.4 & & 5.7 & & 4.9 & & 6.5 & & 8.2 & & 5.6 & \\
\hline & Average & 7.4 & $(7.7)$ & 3.7 & (4.3) & 6.1 & $(6.8)$ & 5.2 & $(5.6)$ & 6.7 & $(7.0)$ & 8.4 & $(8.9)$ & 5.7 & (6.1) \\
\hline \multirow[t]{3}{*}{ D } & Batch 1 & 7.8 & & 4.6 & & 6.9 & & 5.5 & & 7.0 & & 8.2 & & 5.7 & \\
\hline & Batch 2 & 7.4 & & 4.0 & & 6.0 & & 5.0 & & 6.5 & & 8.0 & & 5.6 & \\
\hline & Average & 7.6 & $(7.6)$ & 4.3 & $(4.5)$ & 6.4 & (6.7) & 5.3 & (5.5) & 6.8 & $(6.8)$ & 8.1 & $(8.2)$ & 5.7 & $(6.0)$ \\
\hline
\end{tabular}

${ }^{1}$ Calculated values are given between brackets

\subsection{Laying performance}

\subsubsection{General}

Table 7 provides an overview of the laying performance results from week 39 to 51 . It shows that the crude protein content of the diet affected the laying performance.

The laying hens fed the control diet (Trt A) had the highest average egg weight between week 39 to 51 of age in this experiment. However, the feed intake ( $\mathrm{g} /$ day) and the laying rate $(\%)$ were lower in comparison to the laying hens fed a $14.7 \% \mathrm{CP}$ diet (Trt B). In other words, reducing the crude protein content of the diet to $14.7 \%$ (Trt B) did not affect the egg mass, but the feed conversion ratio increased. The laying hens fed the diets with the crude protein content of $13.5 \%$ (Trt C) and $12.5 \%$ (Trt D) showed a further decline in feed intake ( $\mathrm{g} /$ day), body weight $(\mathrm{g})$, laying rate $(\%)$, egg weight (g), egg mass ( $g /$ day) and FCR in comparison to the control treatment (Trt $A ; 16.1 \% \mathrm{CP}$ ) and Treatment B $(14.7 \% \mathrm{CP})$. A gradual reduction in egg weight was observed among the treatments in line with the reduction in CP content (Figure 6).

In comparison to the control diet (Trt A; $16.1 \% \mathrm{CP}$ ), a reduction of the crude protein up to $13.5 \%$ (Trt C) did not affect the percentage of the second-grade eggs. The crude protein content of the diets did not affect the number of broken eggs produced. However, further reduction of the crude protein content to $12.0 \%$ (Trt D) was associated with an increase of $2^{\text {nd }}$-grade eggs $(1.4 \%$ ), in particular, the numbers of eggs with a shell defect and tiny size were significantly higher in treatment $D$ than the rest of the treatments. According to Table 7, reducing the crude protein content of the diet to $14.7 \%$ or lower was associated with a drop in the production of large-sized double-yolked (jumbo) eggs which were the highest $(0.19 \%)$ in the control treatment. The laying hens fed the diet with $14.7 \%$ CP tended to have the lowest number of eggs with blood spots $(0.09 \%)$ in comparison to the other treatments. 
Table 7 Effects of the crude protein content of the diet on the performance of laying hens from 39 to 51 weeks of age.

\begin{tabular}{|c|c|c|c|c|c|c|c|c|c|c|c|}
\hline Treatment & & $\mathbf{A}$ & & B & & C & & D & & LSD & P-Value \\
\hline CP (Calc) & & $16.1 \%$ & & $14.7 \%$ & & $13.5 \%$ & & $12.0 \%$ & & & \\
\hline CP (Ana) & & $16.2 \%$ & & $14.8 \%$ & & $13.6 \%$ & & $12.5 \%$ & & & \\
\hline Bodyweight & (gram) & 2070 & b & 2064 & b & 2043 & a & 2034 & a & 19.5 & $<0.001$ \\
\hline Feed intake & (g/day) & 123.5 & $\mathrm{~b}$ & 125.0 & c & 122.6 & a & 122.0 & $a$ & 0.88 & $<0.001$ \\
\hline Crude protein intake & (g/day) & 20.0 & d & 18.5 & c & 16.7 & $\mathrm{~b}$ & 15.2 & a & 0.15 & $<0.001$ \\
\hline FCR & & 2.005 & a & 2.031 & $\mathrm{~b}$ & 2.067 & c & 2.073 & c & 0.0138 & $<0.001$ \\
\hline Cum. Mortality 39-51wks & $(\%)$ & $4.3 \%$ & & $4.6 \%$ & & $3.2 \%$ & & $3.9 \%$ & & $3.48 \%$ & 0.800 \\
\hline Laying rate & $(\%)$ & 93.5 & $\mathrm{~b}$ & 94.8 & c & 92.5 & a & 92.7 & a & 0.60 & $<0.001$ \\
\hline \multirow[t]{2}{*}{ Second grade-eggs } & $(\%)$ & 1.18 & $\mathrm{a}$ & 1.08 & $a$ & 1.15 & $\mathrm{a}$ & 1.42 & $\mathrm{~b}$ & 0.180 & 0.002 \\
\hline & $(\%)$ & 0.41 & & 0.42 & & 0.38 & & 0.37 & & 0.086 & 0.625 \\
\hline Jumbo eggs & $(\%)$ & 0.19 & $b$ & 0.07 & $a$ & 0.06 & $a$ & 0.05 & $a$ & 0.059 & $<0.001$ \\
\hline Tiny eggs & $(\%)$ & 0.03 & $a$ & 0.04 & $a$ & 0.04 & $a$ & 0.08 & $b$ & 0.037 & 0.036 \\
\hline Bloody eggs & $(\%)$ & 0.15 & $x y$ & 0.09 & $x$ & 0.20 & $y$ & 0.20 & $y$ & 0.094 & 0.095 \\
\hline Shell defect & $(\%)$ & 0.40 & $a$ & 0.46 & $a$ & 0.47 & $a$ & 0.72 & $b$ & 0.125 & $<0.001$ \\
\hline Egg weight & (g) & 65.9 & d & 65.1 & c & 64.3 & $\mathrm{~b}$ & 63.3 & $a$ & 0.18 & $<0.001$ \\
\hline Egg mass & (g/day) & 61.6 & c & 61.7 & c & 59.3 & $\mathrm{~b}$ & 58.7 & $\mathrm{a}$ & 0.41 & $<0.001$ \\
\hline
\end{tabular}

As was expected, reducing the crude protein content of the diets was associated with a decline in crude protein intake of laying hens. In other words, by the stepwise reduction of the crude protein content from $16.1 \%$ to $12.5 \%$, nitrogen intake reduced gradually from 3.2 to $2.4 \mathrm{~g} /$ day. Figure 6 demonstrates the relationship between the crude protein intake and laying performance in laying hens.
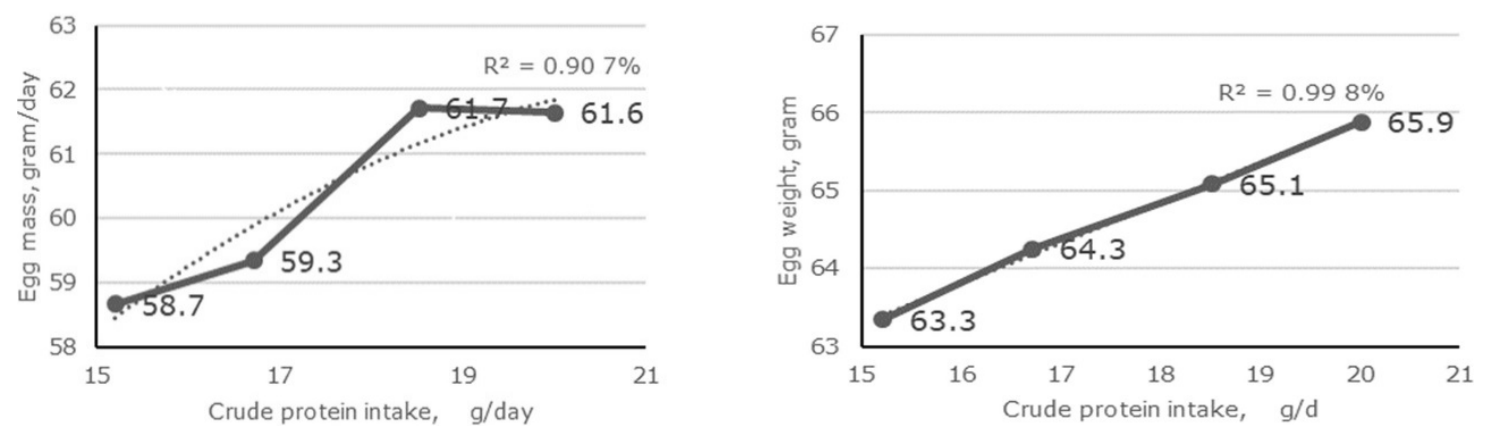

Figure 6 The relationship between the crude protein intake ( $g /$ day) and egg mass (left graph) and egg weight (right graph), among the four treatments of this experiment.

\subsubsection{Nutrient intake of birds}

Table 8 illustrates the average intake of crude protein and total amino acids among the treatments. The crude protein and amino acids intake were significantly different among the treatments. Crude protein intake declined gradually by the stepwise reduction in crude protein content of the dietary treatments. In general, the intake of essential and non-essential amino acids showed a stepwise reduction from Trt $\mathrm{A}(16.1 \% \mathrm{CP})$ to $\operatorname{Trt} \mathrm{D}(12.0 \% \mathrm{CP})$. The exceptions were lysine and methionine as the laying hens fed the diet with $14.7 \% \mathrm{CP}$ (Trt B) had the highest lysine intake among the treatments and the intake of Met+Cys was lower in Trt C than Trt D. In the case of total valine and isoleucine, the difference between the intake of laying hens in treatment $C$ and $D$ was not significant. In spite of the significant effects of reducing dietary crude protein on the intake of amino acids, the magnitude of this reduction was different among essential and non-essential amino acids. In comparison to the control treatment (Trt A; CP 16.1\%), the laying hens in Trt C and D had an average lower intake of essential amino acids which was $6 \%$ for lysine, $8 \%$ for Met+Cys, $11 \%$ for valine and isoleucine, $14 \%$ for 
threonine, and $18 \%$ for arginine. However, the intake of non-essential amino acids in Trt $C$ and $D$ was an average between 19 to $44 \%$ lower than the intake of the laying hens in Trt A and B.

Table 8 The average intake of crude protein ( $\mathrm{g} /$ day) and total amino acids ( $\mathrm{mg} /$ day) based on the feed intake values and the analysed content of nitrogen (wet chemical) and amino acids (EC No 152/2009). in the dietary treatments over the experimental period.

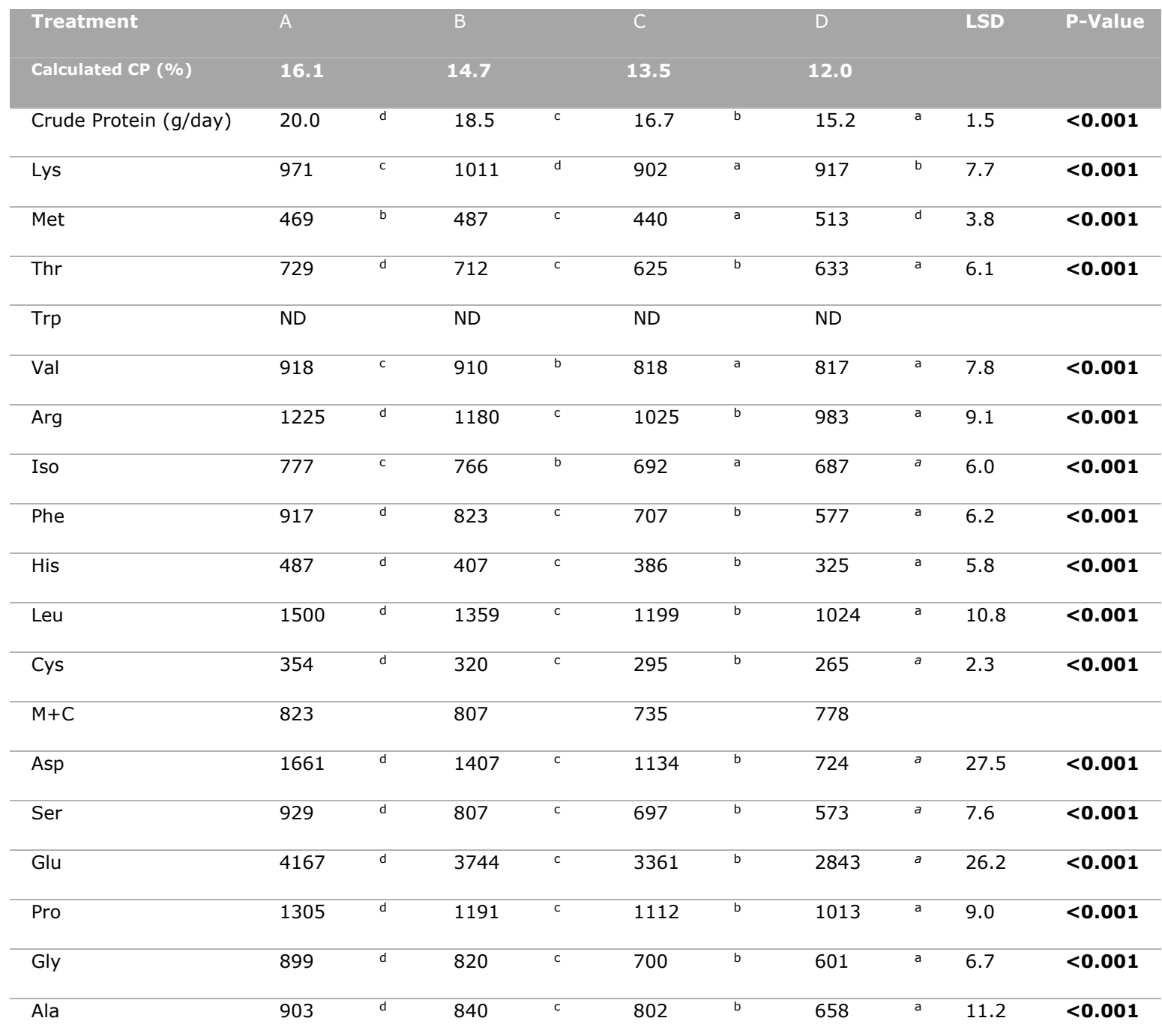

In addition to the crude protein and major limiting amino acids, calcium and phosphorus are the other nutrients with potential effects on the response of laying hens in the case of laying performance and egg quality. Figure 7 illustrates the intake of calcium and total phosphorus among the treatments. The intake of calcium was significantly different among the treatments. Laying hens of treatment $B$ had the highest calcium intake, whereas the hens of treatment $D$ had the lowest calcium intake. Calcium intake of the hens of Trt B differed significantly from Trt D, the Ca-intake of $\operatorname{Tr} A$ and $\operatorname{Tr} C$ were inbetween and did not differ from either Trt B or Trt D. The intake of phosphorus was significantly lower in Trt C (CP 13.5\%) compared to the other treatments. 

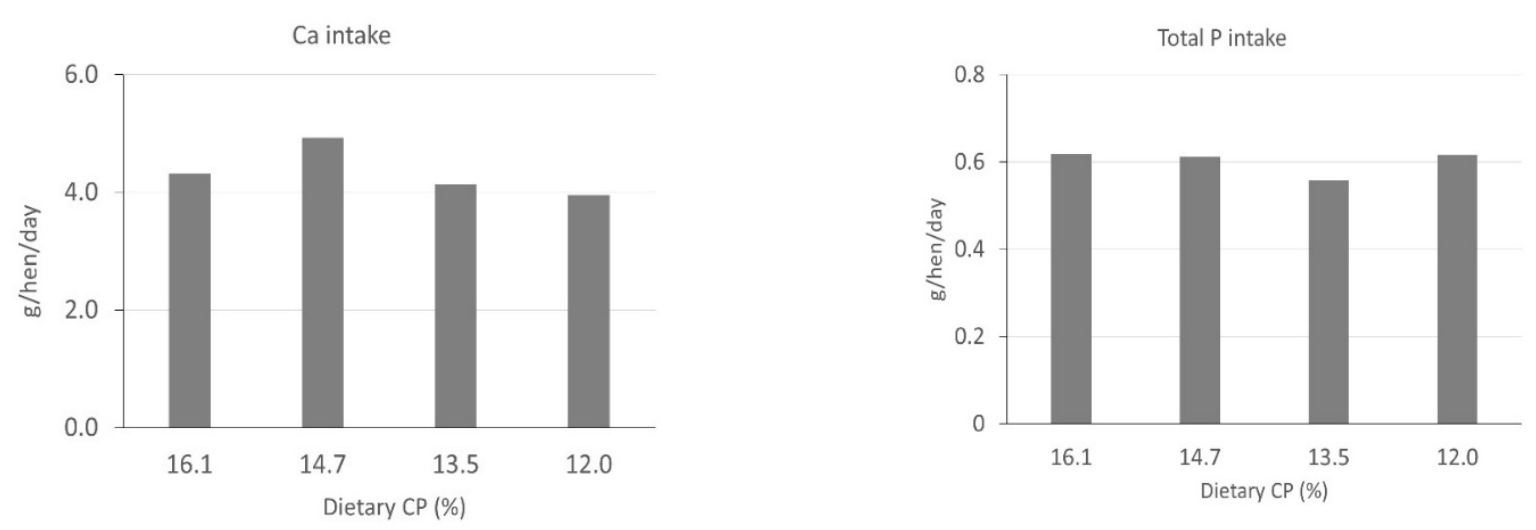

Figure 7 The average intake of calcium and total phosphorus (in $\mathrm{g} /$ day) based on the average feed intake values ( $\mathrm{g} /$ day) and the analysed content of calcium and total phosphorus $(\mathrm{g} / \mathrm{kg})$ in the dietary treatments over the experimental period.

\subsection{Egg quality}

In Table 9, the values of egg characteristics and eggshell quality indicators are given.

Table 9 The effect of the crude protein content of the dietary treatments on egg characteristics and eggshell quality indicators.

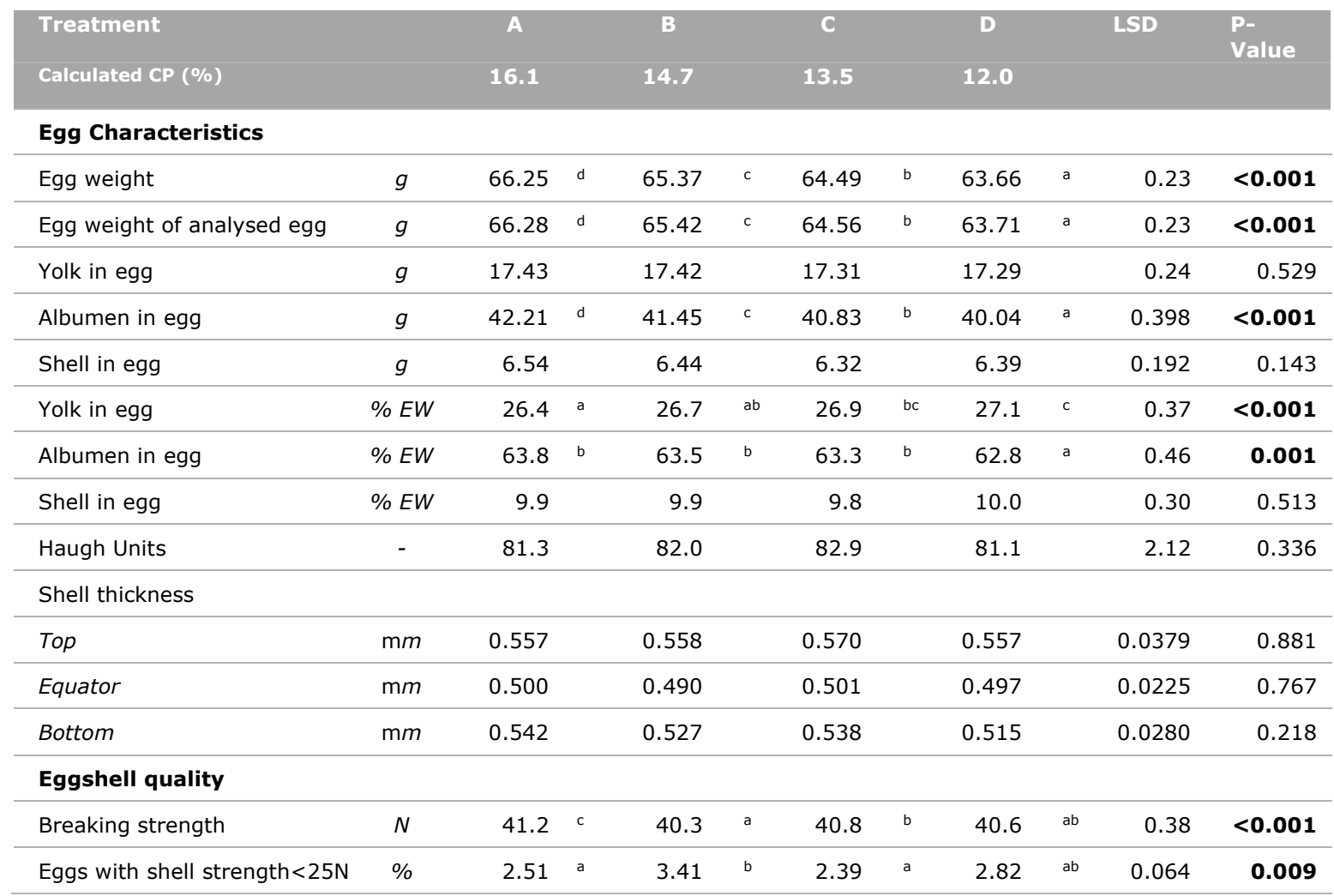

The crude protein content of the diets affected the egg weight, the relative content of albumen and yolk, and the eggshell quality. Reduction in CP content of the diets was associated with a gradual reduction in egg weight and absolute and relative content of albumen. There were no significant differences in Haugh units among the treatments. In the case of eggshells, the crude protein content of the diets did not affect shell content and thickness. Further investigations of eggshell quality characteristics showed that the breaking strength reduced as the laying hens fed the reduced-cp diets (14.7 - 12.0\% CP). The laying hens fed the diet with $14.7 \%$ CP (Trt B) produced a higher percentage of the eggs with shell breaking strength lower than $25 \mathrm{~N}$. 


\subsection{Excreta quality}

Table 10 illustrates the results of the excreta composition assessment. Gradual reduction of the CP content in diets was associated with a stepwise reduction in nitrogen content of manure. According to Figure 8 , the reduction of diet CP from $16.1 \%$ to $14.7 \%$, was associated with a $7.5 \%$ reduction in nitrogen intake (from 3.20 to $2.96 \mathrm{~g} /$ day) and a $12.5 \%$ reduction in nitrogen excretion. It is worth mentioning that the egg mass was similar among these two treatments (see 3.3.1). The effect of the crude protein content of the diet on the moisture content of manure was only significant when CP was reduced to $12.0 \%$ (Trt D). In other words, the rise in DM content of manure from $25.9 \%$ (Trt A) to $26.8 \%$ ( $T r t ~ C)$ was not significant. In addition, the crude protein content of the diet had no significant effect on $\mathrm{NH}_{3}-\mathrm{N} \%$ in the protein content of the manure.

The DM content of the manure of Trt D was significantly higher than the manure of the other three treatments. The dry matter content of the manure did not differ between treatments $A, B$ and $C$.

Table 10 The effect of the crude protein content of the diets on dry matter, nitrogen content and $\mathrm{NH}_{3}-\mathrm{N}$ in excreta at weeks 45 and 51.

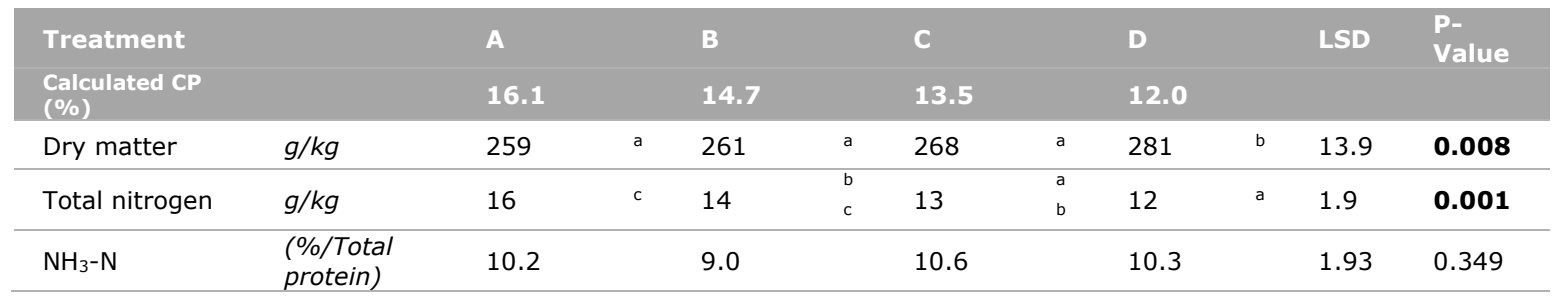

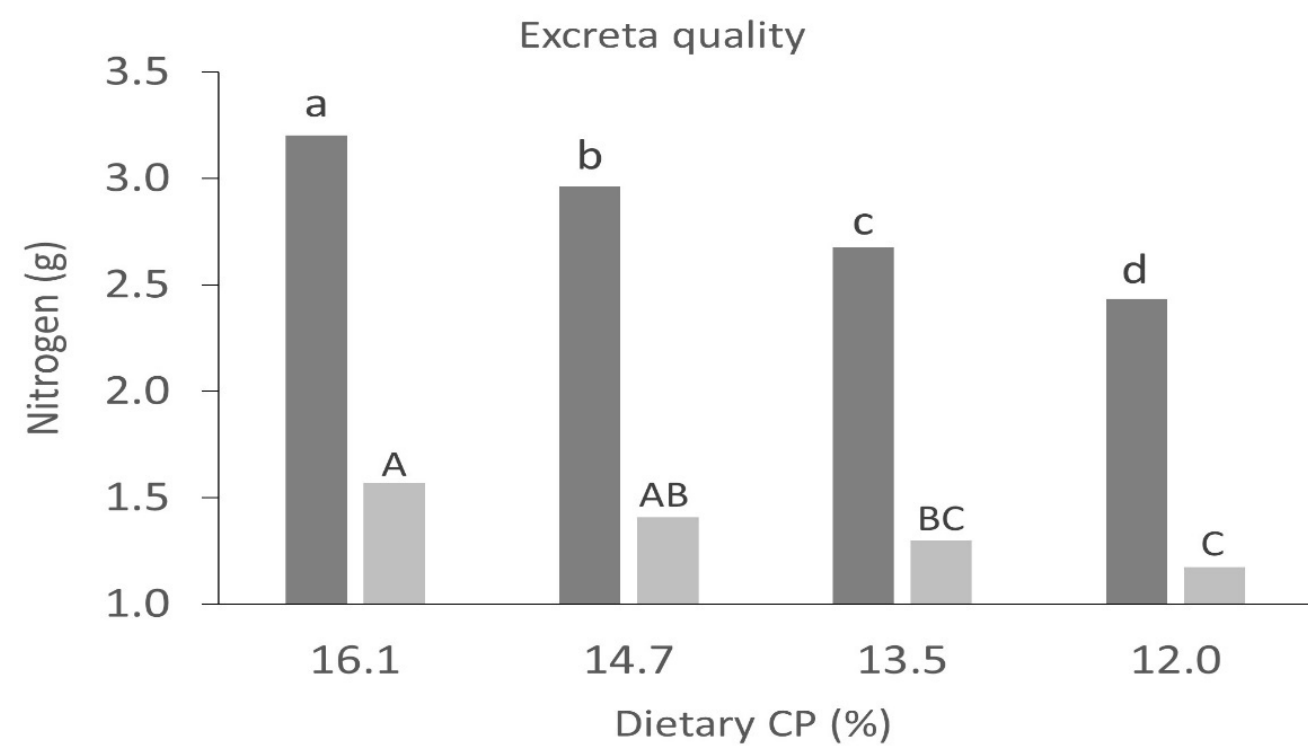

Nitrogen intake (g/day/bird) Nitrogen content of manure (g/100g)

Figure 8 The relationship between the average nitrogen intake ( $\mathrm{g} /$ day) over the experimental period (39 to 51 weeks) and the average nitrogen content of excreta $(\mathrm{g} / 100 \mathrm{~g})$ at weeks 45 and 51 among the treatments.

\subsection{Carbon footprint of the diets and economic feed margin as affected by the dietary treatments}

In Figure 9 the effect of the crude protein content of the diet on the carbon footprint of the diets is given. In Table $11 \mathrm{~A}$ and $11 \mathrm{~B}$, the calculated economic revenues on the farm (feed margins) as affected by the experimental treatments are provided. In appendix 1 and 2 the feed composition of both feed batches is given. In Appendix 4 the contribution of the individual feedstuffs used in the experimental diets on the carbon footprint (CFP) and the calculated CFP per batch of each diet is 
given. Data were generated from the FeedPrint database (Vellinga et al., 2013). The CFPAN tool and database FeedPrint calculates the carbon footprint of feed raw materials during their complete life cycle. This ranges from crop production, via the processing of crops and animal products, compound feed production to utilization by the animal, including transport and storage between all steps of the production chain. For feed prices, the prices of the feed ingredients from January 2021 were taken. From this figure, it can be concluded that a decrease in the crude protein content of layer diets increased the carbon footprint, excluding effects of potential changes in land use (CFP excl. LUC). In the range $16.1-12.0 \% \mathrm{CP}$, each percent lower crude protein leads to an increase of CFP with 40 points.

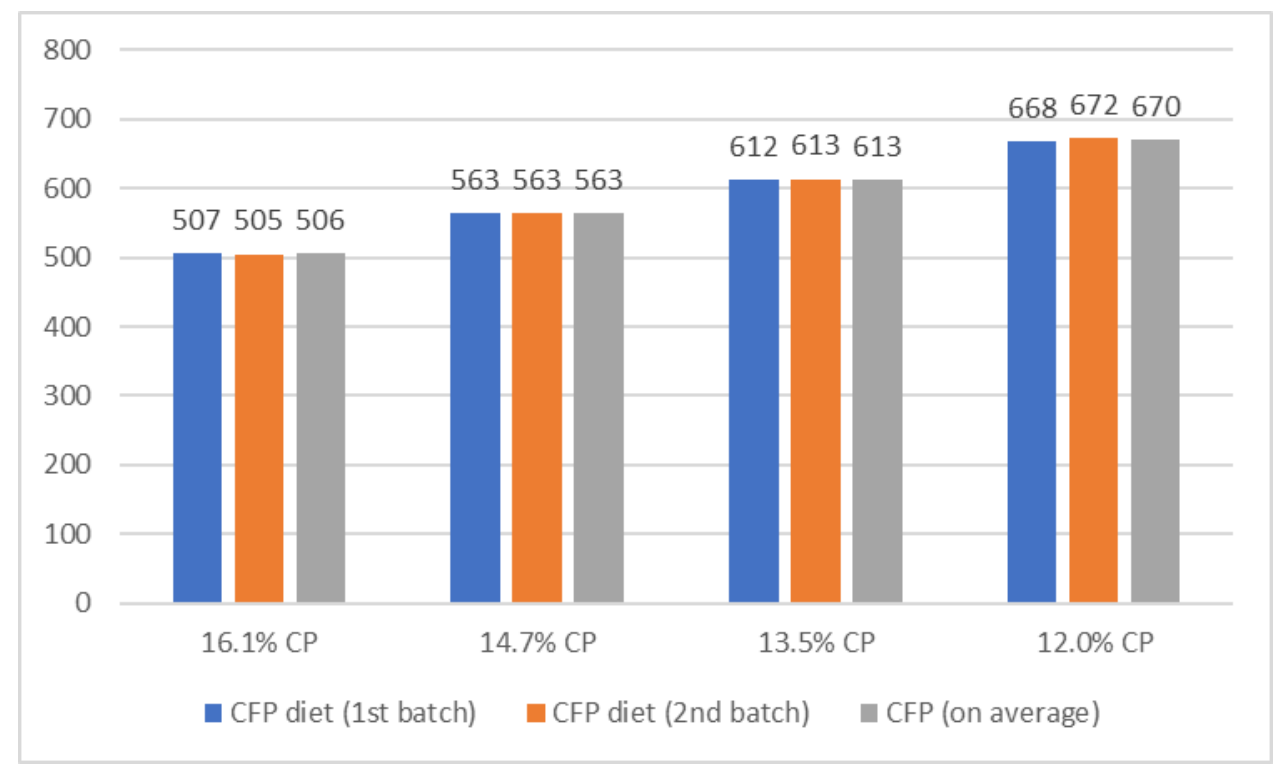

Figure 9 Calculated carbon footprint (excl. LUC, in $\mathrm{CCO}_{2}$-eq/ $\mathrm{kg}$ diet) of the experimental diets.

In Vietnam, the feed price largely depends on the availability and price of the protein sources and the price of free amino acids. At the time of the experiment, sunflower seed meal was sufficiently available in Vietnam and the calculated feed price difference between the $16.1 \% \mathrm{CP}$ control diet and the $12.0 \%$ CP diet was only $3.8 \%$, with the value being higher for the low-protein diet. However, in the current Vietnamese market, sunflower seed meal is not available and soybean meal would become the main protein supplier in the diet, making the $12.0 \% \mathrm{CP}$ diet $8.9 \%$ more expensive than the control diet. In the Netherlands a wide range of protein-rich raw materials is available, so that the price of lowprotein diets is less dependent on the availability of protein sources, but mainly dependent on the price of the free amino acids. Based on the current Dutch raw material prices and prices of the free amino acids, the diet price of the $12.0 \%$ CP diet is 9.5 percent higher than the control diet with $16.1 \%$ $\mathrm{CP}$. Because a wide range of protein sources is available in the Netherlands and the feed price is therefore less dependent on the availability of protein sources, it was decided to base the feed margin calculations on the current Dutch market situation (Table 11A). Assuming that the prices of the free amino acids will decrease in the near future, we also calculated feed margins taking into account a feed price difference between the control diet and the $12.0 \%$ CP diet of $3.8 \%$ (Table 11B).

In the current situation laying hens fed the control diet showed the highest feed margin, whereas the hens fed the $12.0 \% \mathrm{CP}$ diet showed the lowest feed margin. The feed margin of the hens receiving diets with $14.7 \%$ CP was $€ 12.82$ per 100 hens placed lower than the control group. The difference in feed margin between Trt C $(C P=13.5 \%)$ and Trt $D(C P=12.0 \%)$ with the control group was $-€ 56.58$ and $-€ 70.08$ per 100 placed hens, respectively. In the situation that the difference in feed price between the control diet and the $12.0 \%$ CP-diet is only $3.8 \%$, the feed margin of the laying hens fed the $14.7 \%$ CP was slightly higher than the control group ( $€ 125.97$ vs. $€ 125.72$, Table $11 B$ ). The feed margin of the hens receiving diets with $13.5 \%$ and $12.0 \% \mathrm{CP}$ was $€ 30.74$ and $€ 31.67$ per 100 hens placed lower than the control group. 
Table 11A Feed margin (in $€$ per 100 hens placed) at farm level per treatment per flock - current situation.

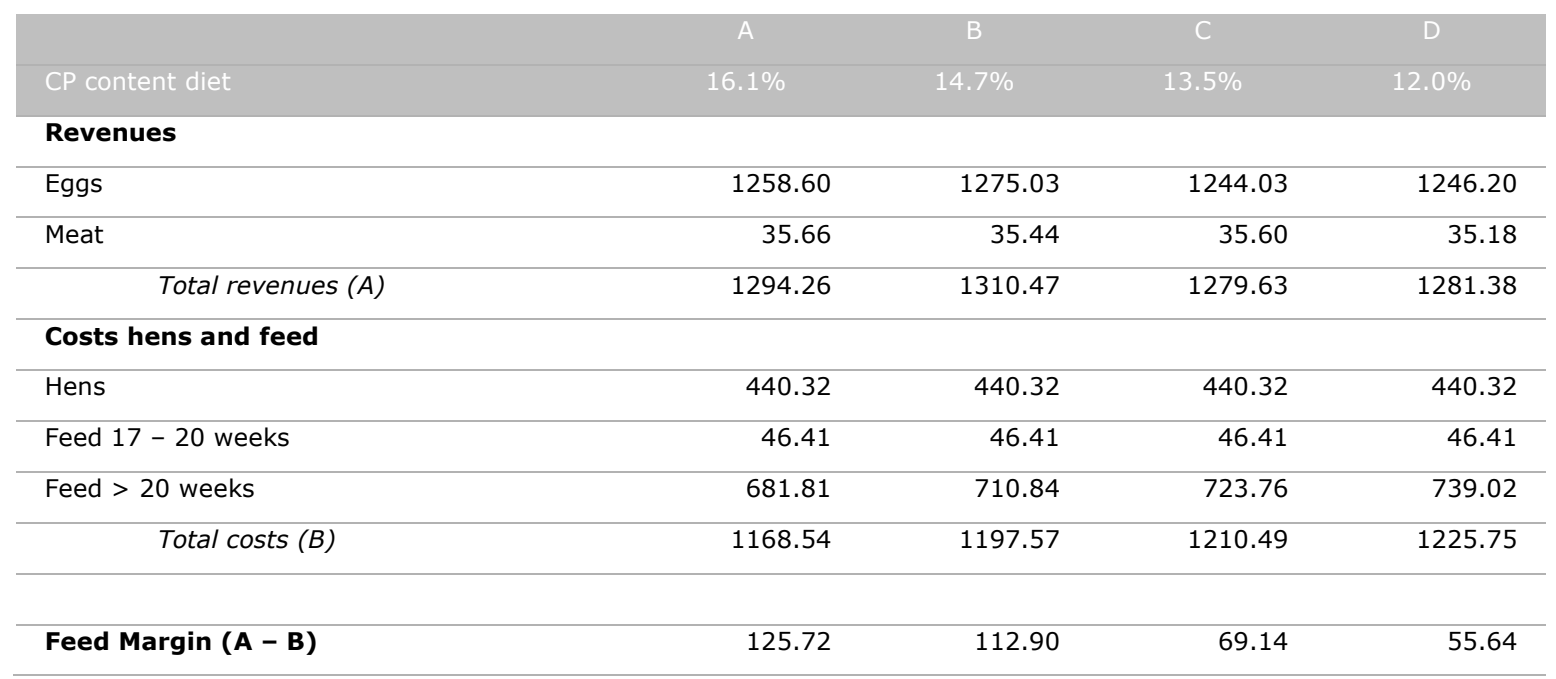

Prices based on KWIN 2020/2021. Egg price: $€ 6.20 / 100$ eggs. Meat price: $€ 0.18 / \mathrm{kg}$. Feed prices: Diet A: $€ 26.00 / 100 \mathrm{~kg}$; Diet B: $€ 26.82 / 100 \mathrm{~kg}$; Diet C: $€ 27.65 / 100 \mathrm{~kg}$; Diet D: $€ 28.47 / 100 \mathrm{~kg}$.

Table 11 B Feed margin (in $€$ per 100 hens placed) at farm level per treatment per flock - future scenario.

\begin{tabular}{|c|c|c|c|c|}
\hline & A & B & C & D \\
\hline CP content diet & $16.1 \%$ & $14.7 \%$ & $13.5 \%$ & $12.0 \%$ \\
\hline \multicolumn{5}{|l|}{ Revenues } \\
\hline Eggs & 1258.60 & 1275.03 & 1244.03 & 1246.20 \\
\hline Meat & 35.66 & 35.44 & 35.60 & 35.18 \\
\hline Total revenues $(A)$ & 1294.26 & 1310.47 & 1279.63 & 1281.38 \\
\hline \multicolumn{5}{|l|}{ Costs hens and feed } \\
\hline Hens & 440.32 & 440.32 & 440.32 & 440.32 \\
\hline Feed 17 - 20 weeks & 46.41 & 46.41 & 46.41 & 46.41 \\
\hline Feed $>20$ weeks & 681.81 & 697.77 & 697.92 & 700.60 \\
\hline Total costs $(B)$ & 1168.54 & 1184.51 & 1184.65 & 1187.33 \\
\hline Feed Margin (A - B) & 125.72 & 125.97 & 94.98 & 94.05 \\
\hline
\end{tabular}

Prices based on KWIN 2020/2021. Egg price: $€ 6.20 / 100$ eggs. Meat price: $€ 0.18 / \mathrm{kg}$. Feed prices: Diet A: $€ 26.00 / 100 \mathrm{~kg}$; Diet B: $€ 26.33 / 100 \mathrm{~kg}$; Diet C: $€ 26.66 / 100 \mathrm{~kg}$; Diet D: $€ 26.99 / 100 \mathrm{~kg}$. 


\section{Discussion}

In this study, laying hens between 39 to 51 weeks of age fed iso-energetic diets with a reduced content of crude protein ( $16.1 \%$ vs $14.7 \%, 13.5 \%$, and $12.0 \%)$ supplemented with commercially available free essential amino acids up to CVB recommendations (CVB, 2018). This study aimed to evaluate the effect of low protein diets on laying performance, egg quality, N-efficiency, N-excretion, farm economics/feed margin and carbon footprint. The experiment was performed at the experimental layer facility in a tropical climate in Vietnam and the laying hens were kept in battery cages in a mechanical ventilated house. The results showed that lowering the crude protein content of the diets from $16.1 \%$ to $14.7 \%$, by partial replacement of soybean meal and sunflower seed meal, resulted in similar egg mass in laying hens between 39 to 51 weeks of age. Further lowering of the crude protein content deteriorated the production performance. The laying hens fed the $13.5 \%$ or $12.0 \%$ CP diets had a significantly lower laying rate, egg weight, and feed efficiency compared with the hens fed the control diet (16.1\% CP) and the hens fed the $14.7 \% \mathrm{CP}$ diet.

Reducing the crude protein content of diets in laying hens has been the aim of several studies and the increasing availability of free amino acids such as Met, Lys, Thr, Trp, Val, Ile and Arg for diet supplementation facilitates the implementation of the concept. The aims are, on the one hand, to reduce nitrogen excretion and to improve $\mathrm{N}$-efficiency, and on the other hand to reduce the dependency on imported soybean meal from countries outside Europe, mainly Latin America. However, studies on the subject in laying hens show in part contrasting results, as further outlined below.

Reducing the dietary crude protein from $18 \%$ to $15 \%$ had no effects on egg mass and laying rate in laying hens between 21 to 72 weeks (Rao et al., 2011). Mousavi et al. (2013) also observed a similar laying rate in laying hens fed a reduced CP diet (15.5\% vs $18.5 \%$ CP) between 25 to 33 weeks of age. Keshavarz \& Austic (2004) found that hens fed a low crude protein diet (13\% CP) supplemented with free essential amino acids had a comparable laying performance with the control diet with 16-16.5\% CP. Recently, Parenteau et al. (2020) reported that CP in laying hen diets between the age of $28-46$ weeks can be reduced by $2 \%$ units (from 16 to $14 \%$ ) as long as it is fortified with synthetic AA (Met, Lys, Thr, Trp and Ile). These studies concluded that supplying the low protein diets with free amino acids met the requirements of the laying hens to have the same laying performance as the control diets.

Stepwise reduction of the dietary crude protein from $18 \%$ to $16 \%$ in laying hens between 21 to 34 weeks of age affected the average egg weight. Laying hens fed the 16 to $16.5 \%$ CP diet had $2-3 \%$ lower average egg weight while the changes in feed intake, feed efficiency, and laying rate were not significant (Ji et al., 2014). In contrast, the results of several studies indicated negative effects of low protein diets on laying performance (Azzam et al., 2017a; Wang et al., 2020). In the present study, the reduction of the crude protein content of the diet up to $14.7 \%$ did not affect egg mass, but a further reduction to $13.5 \%$ and $12.0 \%$ reduced feed intake, body weight, laying rate, and egg mass, despite supplementation of essential AA.

Several factors cause this inconsistency which could be related to the characteristics of the experimental diets (e.g. basal diet composition, feed ingredients, metabolisable energy content), laying hens (e.g. strain and age), environmental conditions (climate, temperature, and humidity) or interacting factors, for example, the feed intake which is influenced by the animal-related (e.g. age) and diet-related (e.g. ME content and concentrations of other nutrients) factors, and environmental conditions such as temperature or the housing system.

One critical factor is the extent to which crude protein was reduced or free amino acids were supplemented to the experimental diets. For example, reducing the crude protein content of the diet to $9.2 \%$ impaired the laying performance in comparison to the laying hens fed a $16.5 \% \mathrm{CP}$ diet, between 28 to 32 weeks of age (Wang et al., 2020). However, the low protein diets in the abovementioned studies had a crude protein content of 15.5\% (Mousavi et al., 2013) or 15\% (Rao et al., 2011). Besides that, in the study of Mousavi et al (2013), the levels of digestible lysine $(0.87 \%$ vs $0.69 \%)$, threonine $(0.62 \%$ vs $0.48 \%)$, arginine $(0.93 \%$ vs $0.75 \%)$, and isoleucine $(0.60 \%$ vs $0.55 \%)$ were higher than the levels in the diets in our study. The reason for the higher contents of the essential amino acids could be the younger age of the laying hens ( 25 to 33 weeks) when hens are 
highly productive and related amino acid requirements are high, compared with the age of the laying hens over the experimental period in our study (39 to 51 week).

Another reason for inconsistencies in the results is the difference in the intake of other nutrients. For example, laying hens fed a diet with $250 \mathrm{kcal} / \mathrm{kg}$ higher metabolizable energy had a higher body weight and a higher laying performance in battery cages in a tropical region, regardless of the diet crude protein content (15\% to $18 \%$ CP) (Rao et al., 2011). In our study, feed intake was lower in the laying hens fed $13.5 \%$ and $12.0 \%$ CP diets which reduced the intake of other nutrients, as well. The inconsistencies among the studies resulted in contrasting conclusions on the effectiveness of free amino acids supplementation in low crude protein diets to prevent the drop in laying performance

In the present experiment, the feed intake was lower in laying hens fed the diets with $13.5 \%$ or $12.0 \%$ CP compared with the diets with 14.7 or $16.1 \%$ CP. In contrast, feed intake increased (101.9 vs $104.1 \mathrm{~g} /$ day) as laying hens fed a low crude protein diet $(15.5 \%$ vs $18.5 \% \mathrm{CP})$ with the same content of the essential amino acids (Mousavi et al., 2013). Considering the similar content of digestible amino acids among diets, the higher feed intake of the laying hens fed the low crude protein diet led to a higher intake of essential amino acids. The laying rate (\%)was similar regardless of the crude protein content of the diets, however, the egg weight, body weight and feed efficiency decreased (Mousavi et al., 2013). A similar feed intake when laying hens fed a 14\% CP diet instead of a $16 \%$ CP diet prevented a drop in egg weight (Bunchasak \& Silapasorn, 2005). In contrast, Shim et al (2013) suggested that the drop in feed intake was the reason for the deteriorated laying performance in laying hens fed a low crude protein diet (4\% CP lower than control) supplemented with EAA. In the current study, reducing the crude protein content of diets to $13.5 \%$ and $12.0 \%$ was associated with a drop in feed intake and an impaired laying performance.

The drop in feed intake in chickens fed a low protein diet has been observed in other studies (Viana, 2017; Shim et al., 2013; Wang et al., 2020) and several reasons have been suggested. Shim et al. (2013) suggested that the laying hens reduced the feed intake in response to a drop in the dietary CP content because the limited availability of protein had impaired the egg size and laying rate which reduced the energy requirement of the laying hens. In contrast, the laying hens increased the feed intake in response to a higher level of dietary $\mathrm{CP}$ to provide the required energy to synthesise protein for egg formation. It indicates that the supplemented amino acids in the reduced protein diets did not meet the requirements of the laying hens for egg production, therefore, the feed intake did not increase.

Viana (2017) discussed four reasons for the drop in feed intake when laying hens fed a reduced protein diet (CP 17\% vs 13\%) supplemented with EAA. Firstly, the lower heat increment in reduced-CP diets could increase the net energy value which affects the feed intake. Secondly, the more rapid intestinal absorption of free amino acids could lead to amino acid imbalances in the postabsorptive metabolism of amino acids. Thirdly, the high level of free amino acids could affect appetite regulation. Lastly, it was emphasised that the balance between the nitrogen being supplied by EAA and NEAA could affect performance in laying hens and it is critical to find an ideal balance. In other words, the lower content of NEAA in reduced-CP diets increases the ratio of EAA to NEAA, in particular in the diets that are supplemented with free EAA. Therefore, the amount of dietary nitrogen could become limiting and EAA would be used as a nitrogen source rather than for their specific functions. In the present study, the content of NEAAs reduced gradually by the stepwise reduction in crude protein content led to an imbalance in the content of NEAA and the rise in the ratio of EAA to NEAA in the low crude protein diets.

Differences in the kinetics of intestinal absorption of free and protein-bound amino acids have been recently suggested in broilers (Selle \& Liu, 2018), however, to the best of our knowledge, the potential differences in the absorption rate, utilisation in enterocytes, and post-absorptive metabolism between free and protein-bound amino acids have not been studied yet in laying hens.

Regarding the effects of amino acids on satiety stimulation in laying hens, it has been shown that supplementing a reduced-CP diet (CP 13\%) with $79.2 \mathrm{~g} / \mathrm{kg}$ glutamic acid reduced the feed intake ( $93.4 \mathrm{vs} 90.7 \mathrm{~g} / \mathrm{kg}$ ) in laying hens between 28 and 44 weeks of age, while supplementing $37.6 \mathrm{~g} / \mathrm{kg}$ glutamic acid in a 15\% CP diet did not affect feed intake in comparison to diets with the same level of CP (Viana, 2017). The author considered the anorectic effects of glutamic acid as a neurotransmitter in chickens to cause a drop in feed intake (Viana, 2017). It is not the case in the present study, as the content of glutamic acid, as well as other non-essential amino acids, gradually declined by reducing the crude protein content of the diets. Further understanding the pathways by which the non-essential amino acids affect satiety in laying hens and the importance of NEAA concentration in diets, could facilitate the application of low crude protein diets in laying hens. 
According to a study reviewed the outcome of research in amino acids requirements of laying hens being published between 1994 and 2019, supplying low protein diets with a lysine content of over 8.0 $\mathrm{g} / \mathrm{kg}$ might reduce feed intake (Macelline et al., 2021). Wang et al (2018) emphasized the regulatory role of amino acids on the appetite centres in CNS and argued that a high level of lysine might suppress the appetite in chickens by the means of L-pipecolic acid, an important metabolite of lysine in the brain. In the current study, the $14.7 \%$ CP diet had the highest lysine content $(8.2 \mathrm{~g} / \mathrm{kg})$. The laying hens fed this diet had the highest feed $(125 \mathrm{~g} /$ day $)$ and lysine $(1011 \mathrm{mg} /$ day $)$ intake across the treatments. In contrast, the lower content of lysine $(7.4-7.6 \mathrm{~g} / \mathrm{kg}$ ) in diets with $12.0 \%$ and $13.5 \% \mathrm{CP}$ was associated with a drop in feed intake and laying performance. It might indicate that a rise in lysine content even more than $8.0 \mathrm{~g} / \mathrm{kg}$ might prevent the drop in laying performance in the case of low CP diets. In our study, the imbalance of amino acids due to the large reduction of the nonessential amino acids in $13.5 \%$ and $12.0 \%$ CP diets (Figure 11 ) along with the rise in free essential amino acids could have impaired the feed intake of the hens.

Bunchasak \& Silapasorn (2005) suggested the imbalance in amino acids content of the low crude protein diets, in particular methionine content, as the reason for the drop in feed intake in laying hens. It was shown that the feed intake in laying hens consumed either $14 \%$ or $16 \%$ CP diets were similar in the case that diets contained $3.8 \mathrm{~g} / \mathrm{kg}$ methionine (Bunchasak \& Silapasorn, 2005). The results of studies in laying hens stated a linear positive relationship between total sulfur-containing amino acids (TSAA) content of the diets and feed intake (Carvalho et al., 2018). In our study, the intake of TSAA was 5 to $10 \%$ higher in the laying hens fed $16.1 \%$ and $14.7 \%$ CP diets which were associated with a higher feed intake in comparison to the low crude protein diet treatments. Besides that, TSAA content was higher (6.4 vs $6.1 \mathrm{~g} / \mathrm{kg}$ ) in the $12.0 \%$ CP diet (Trt D) than the $13.5 \%$ CP diet (Trt C), while the feed intake of the laying hens between these two dietary treatments were similar. It suggests that increasing the content of TSAA might prevent a further drop in feed intake in very low CP diets.

In general, there are two approaches in diet formulation in studies on the response of laying hens to low protein diets. Firstly, the ratio of amino acids to crude protein remained constant while the crude protein content reduced gradually (Rao et al., 2011; ji et al., 2014; Torki et al., 2017). Secondly, the content of amino acids remained constant while crude protein content reduced gradually (Mousavi et al., 2013). In the present study, the diets were formulated to have similar concentrations of digestible, first limiting essential amino acids. However, the analysed contents of total amino acids indicated slight differences between the analysed and calculated concentrations, somewhat varying between treatments (Table 6). Deviations from the expected content of amino acids along with the significant differences in feed intake among the treatments, affected the intake of digestible amino acids by the laying hens. In general, the intake of amino acids in laying hens fed $13.5 \%$ and $12.0 \%$ CP diets was lower than the dietary treatments with $14.7 \%$ and $16.1 \%$ CP (Table 8 ). Reduction in the crude protein or essential amino acids intake in addition to the imbalance of amino acids led to a decreased laying performance (Mousavi et al., 2013).

In fact, there was a linear relationship between the crude protein intake and the bodyweight of the laying hens in the current experiment. The laying hens fed the $13.5 \%$ or $12.0 \% \mathrm{CP}$ diets had on average 16.7 or $15.2 \mathrm{~g}$ /day crude protein intake and these hens had a lower body weight and laying rate compared to the hens fed diets with $14.7 \%$ or $16.1 \% \mathrm{CP}$ which had a crude protein intake of 18.5 or $20 \mathrm{~g} /$ day, respectively. The drop in body weight, egg weight, and absolute and relative content of albumen in eggs might indicate that protein synthesis was limited. Besides essential amino acids, the intake of non-essential amino acids was lower in these treatments. Considering the existence of potential differences in the absorption and post-absorptive metabolism between free and proteinbound amino acids, high content of free EAA in reduced-CP diets might cause an imbalance in the post-absorptive profile of amino acids (Selle \& Liu, 2018). The existence of this phenomenon in laying hens requires further study to reach an ideal amino acids balance.

Moreover, the low intake of NEAAs could exacerbate the limiting effects of EAA in reduced-CP diets by enhancing the conversion of EAAs which impair protein synthesis (Novak et al., 2006; Rao et al., 2011; Wang et al., 2020). In a study on the interaction of lysine content and low crude protein diets on laying performance of laying hens between 21 to 72 weeks of age, Rao et al. (2011) showed the limiting effect of low NEAAs on the performance response of laying hens fed the low protein diet. In other words, when dietary protein decreases to a relatively low level, a detrimental influence on laying performance may appear. The requirement for the nonessential amino acids was suggested to be one of the underlying reasons for the decreased laying performance at low protein diets (Han et al., 1992), however, requirement values for NEAA are not yet available for laying hens.

In the present experiment, the intake of amino acids reduced gradually by the stepwise reduction in the crude protein content of the diets. Therefore, laying hens fed the $13.5 \%$ and $12.0 \%$ CP diets had 
the lowest intake of essential as well as non-essential amino acids. Methionine is the first limiting amino acid in poultry feed (Carvalho et al., 2018). Increasing the methionine content (4.4 vs 3.8 $\mathrm{g} / \mathrm{kg}$ ) of a low protein diet (14\% CP) prevented the drop in feed intake while the intake of crude protein and other amino acids was still lower than the control diet (16\% CP) (Bunchasak \& Silapasorn, 2005). The higher methionine intake (440 vs $373 \mathrm{mg} /$ day) in laying hens between the age of 24 to 44 weeks improved the egg weight to the same level as the control diet while the egg mass and feed efficiency were still deteriorated (Bunchasak \& Silapasorn, 2005). Kakhki et al. (2016) suggested that $710 \mathrm{mg} / \mathrm{d}$ TSAA is required for optimum egg production and $641 \mathrm{mg} / \mathrm{d}$ for optimum egg weight in laying hens (Hy-line W36) between the age of 32 to 44 weeks. In our study, TSAA intake of $779 \mathrm{mg} / \mathrm{d}$ did not prevent the drop in laying performance when laying hens fed a $12.0 \%$ CP diet.

Another example of the lower EAA intake in our study is threonine, the third limiting amino acid (Fernandez et al., 1994). Azzam et al (2017) found that supplying free amino acids to a low protein diet $(14.1 \%$ vs $16.1 \%)$ prevented the drop in laying performance in Lohman Brown laying hens between 29 to 40 weeks of age. However, a reduction in threonine intake from 562 to $467 \mathrm{mg} / \mathrm{day}$ in laying hens fed the low protein diets, impaired the laying performance. Azzam et al (2017) stated that a digestible threonine content of 5.7 or $6.6 \mathrm{~g} / \mathrm{kg}$, corresponding to 652 or $757 \mathrm{mg}$ daily threonine intake, ensured the highest laying performance. In our experiment, the digestible threonine content was higher in diets with CP content of 16.1 and $14.7 \%$ than the diets with the crude protein content of 13.5 and $12 \%(5.2 \mathrm{vs} 4.8 \mathrm{~g} / \mathrm{kg}$ ) which affected the threonine intake. The laying hens with a threonine intake of $712-729 \mathrm{mg} /$ day (Trt A \& B) had a higher laying performance in comparison to the laying hens with a threonine intake of $625-633 \mathrm{mg} /$ day (Trt C \& D). Therefore, the result of our experiment related to threonine was in line with the observations in the literature.

In the present study, the laying hens fed the $13.5 \%$ and $12.0 \%$ CP diets (Trt C \& D) had a lower intake of essential and non-essential amino acids in comparison to the laying hens fed the $14.7 \%$ and $16.1 \%$ CP diets. However, it is disputable to suggest that the digestible EAA intake met the requirement of the laying hens in Trt $C \& D$ or caused marginal deficiencies and imbalance of EAA. The intake of NEAA in the laying hens in Trt $C \& D$ was remarkably lower than the laying hens in Trt $A \& B$, however, the daily requirement of the NEAA has not been studied yet. Moreover, the lack of nitrogen to synthesise NEAA could impair protein synthesis and lead to metabolic degradation of EAA, as well. This possibility along with the potential differences in the intestinal absorption of free and proteinbound EAA could impair the timely availability of all required amino acids for maximum protein synthesis in organs and tissues.
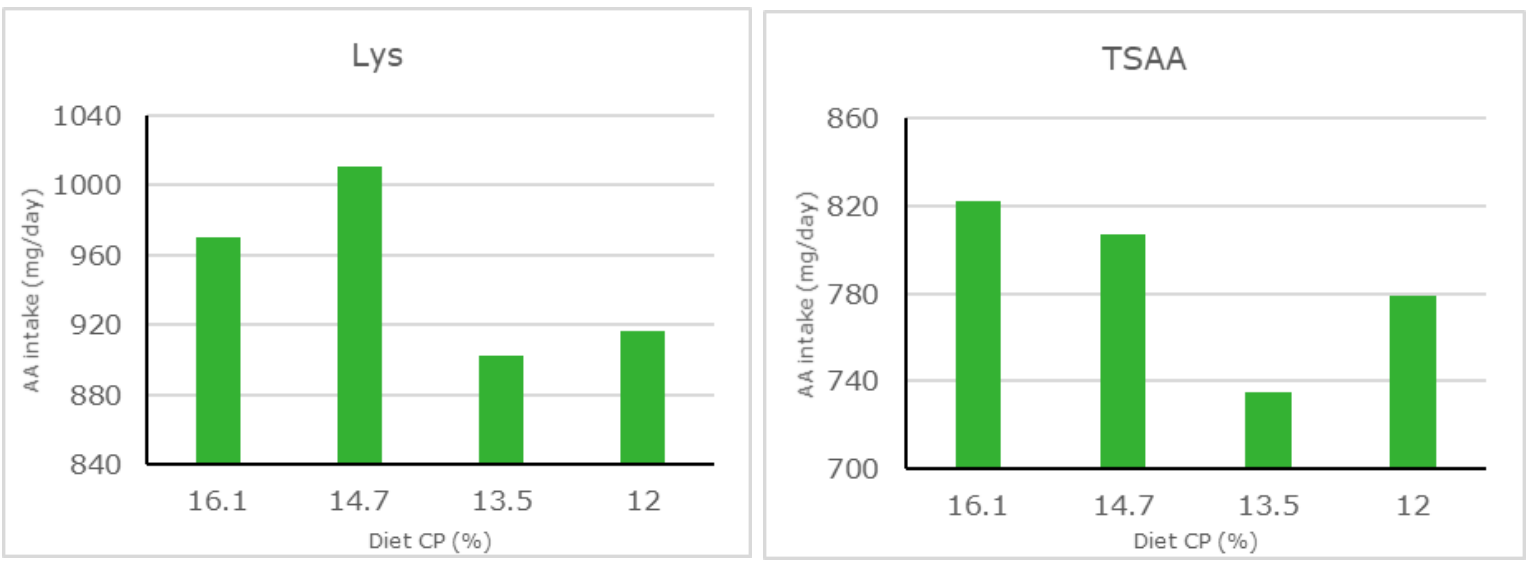

Figure 10 Average intake ( $m g / d a y$ ) of lysine and total sulphur-containing amino acids (TSAA) based on the average feed intake ( $\mathrm{g} / \mathrm{day})$ and the analysed content of amino acids $(\mathrm{g} / \mathrm{kg}$ ) in each dietary treatment, between week 39 to 51. Note: recommended daily intake of total lysine and TSAA in laying hens up to the age of 55 weeks is $980 \mathrm{mg} /$ day and 860 mg/day, respectively (Hendrix Genetics, 2020). 


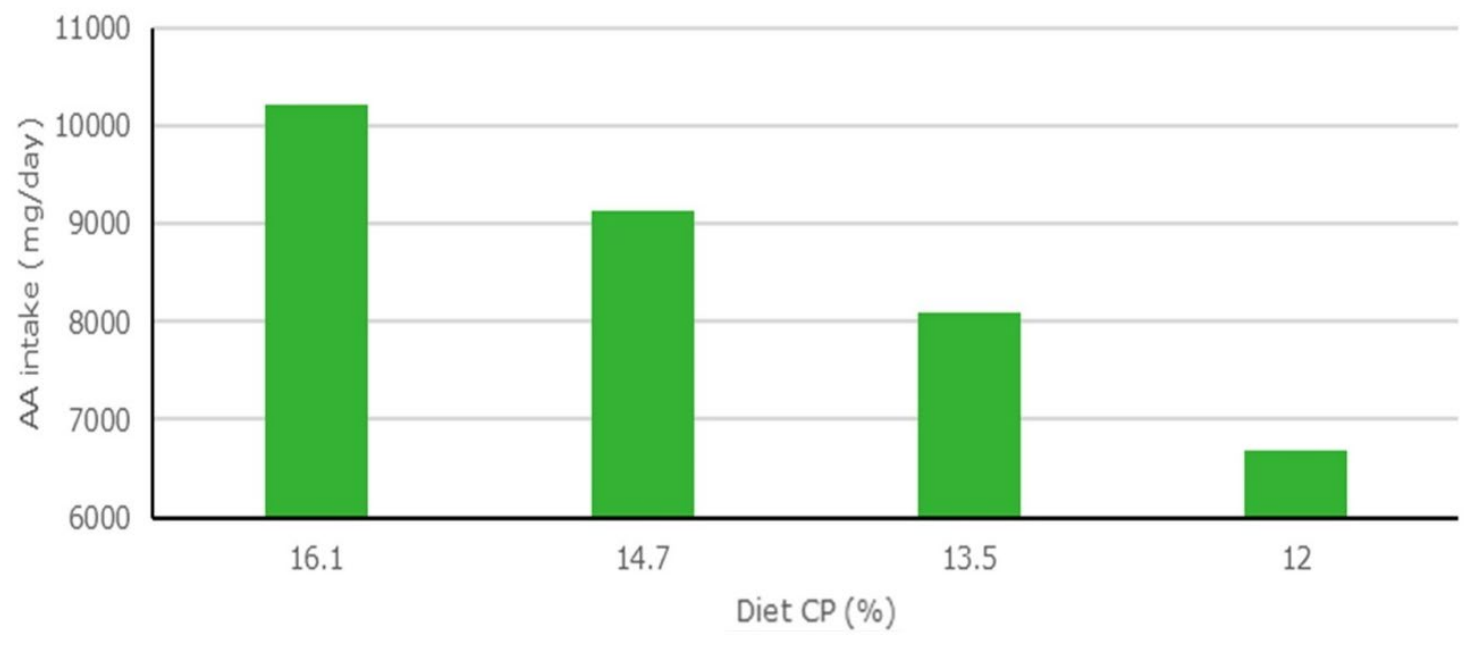

Figure 11 Average intake (mg/day) of non-essential amino acids (NEAA) based on the average feed intake ( $\mathrm{g} /$ day) and the analysed content of amino acids in each dietary treatment, between weeks 39 to 51 .

In the present experiment egg weight decreased linearly ( $65.9 \mathrm{vs} 63.3 \mathrm{~g}$ ) with the stepwise reduction of crude protein content in diets (Table 9 and Figure 12). Stepwise reduction of diet CP from $18.5 \%$ to $15.5 \%$ did not affect laying rate (\%) in laying hens between 25 to 33 weeks of age, however, the egg weight reduced gradually ( 57.1 vs $55.9 \mathrm{~g}$ ) (Mousavi et al., 2013). In spite of supplementing free amino acids to the low crude protein diet, egg weight reduced in the laying hens and the lower intake of crude protein was suggested as the reason for the drop in egg weight (Mousavi et al., 2013; Novak et al., 2006).

While it is generally accepted that the content of NEAA is adequate in the laying hen diets, in the low $\mathrm{CP}$ diets the dietary nitrogen content to synthesise NEAA could become limiting. In fact, NEAA such as glycine and glutamine are critical sources of nitrogen. The limited intake of NEAA in the case of low protein diets impaired the protein synthesis in the laying hens which might be reflected as a drop in body weight or albumen synthesis for egg production. In our study, the drop in egg weight was associated with the reduction in the absolute content of albumen (42.2 to $40.0 \mathrm{~g} / \mathrm{egg}$ ) in eggs. In laying hens fed the $12.0 \% \mathrm{CP}$ diet, the relative content of albumen (\%/egg) was significantly lower than the eggs from other treatments. In laying hens fed low protein diets supplemented with free amino acids, the intake of crude protein and non-essential amino acids declined which could impair protein synthesis in the body. Several researchers (Mousavi et al., 2013 and Torki et al., 2017) suggested that in laying hens fed low protein diets with similar content of major essential amino acids, the reduction in protein synthesis could be the cause of the drop in egg weight and body weight. In our study, body weight, egg weight, albumen content of the eggs, and in the extreme case (Trt D) the relative content of albumen in eggs declined in response to the reduced intake of crude protein and amino acids across the treatments.

Regarding the limiting role of low NEAA content in reduced-CP diets in laying hens, Viana (2017) showed that supplying glutamic acid $(38 \mathrm{~g} / \mathrm{kg}$ ) to a reduced-CP diet ( $15 \%$ vs $17 \% \mathrm{CP}$ ) in laying hens between 28 and 44 weeks of age increased egg weight and improved FCR to the same values as the laying hens fed the control diet. In other words, in laying hens fed a reduced CP diet (15\% vs $17 \%$ $\mathrm{CP}$ ), the egg weight ( 62.8 vs $65.0 \mathrm{~g}$ ), egg mass ( $53.8 \mathrm{vs} 55.9 \mathrm{~g})$, and feed conversion ratio (1.76 vs 1.70) were impaired, however, supplementing $38 \mathrm{~g} / \mathrm{kg}$ glutamic acid to the $15 \%$ CP diet increased the egg weight $(64 \mathrm{~g})$, egg mass $(55.3 \mathrm{~g})$, and improved the FCR $(1.71)$ to the similar level as the laying hens in the $17 \%$ CP dietary treatment. The rise in performance by including glutamic acid in the reduced-CP diet indicated that the glutamic acid level was limiting. Another explanation is supplementing glutamic acid in the reduced-cp diet could provide enough nitrogen for protein synthesis. In fact, the researchers at Texas A\&M University suggested that the requirements of laying hens for NEAA could be higher than the content in the conventional diets. Therefore, the content and ratio of the non-essential amino acids in laying hen diets should be considered in the Ideal Protein concept, even in conventional diets (He et al., 2021). 


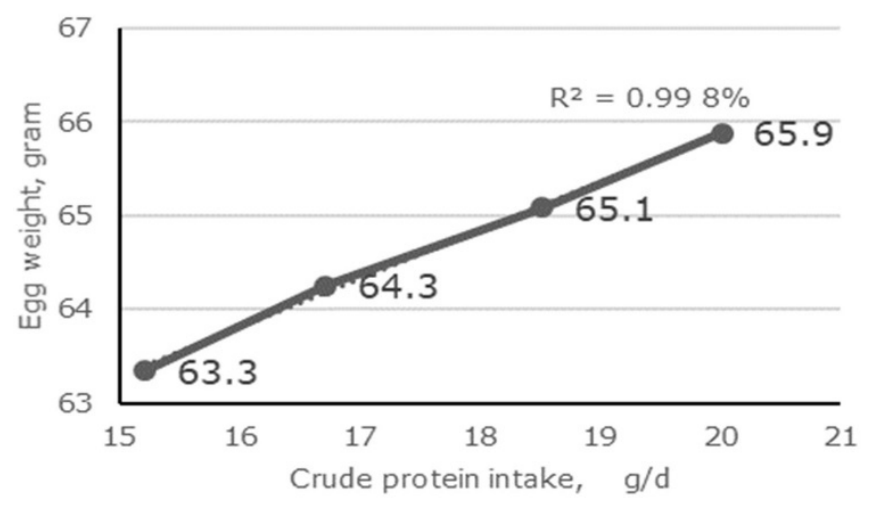

Figure 12 Correlation between crude protein intake and egg weight of laying hens from 39 - 51 weeks of age.

Haugh unit of eggs is an important indicator of egg quality parameter related to egg protein content and egg freshness. In the current study, the crude protein content of diets did not affect the Haugh unit, while the relative content of albumen (\%/egg weight) was reduced in laying hens consumed the $12 \%$ CP diet. This finding is in line with the outcome of several studies (Alagawany \& El-hindawy, 2020; Azzam et al., 2017b). A drop in Haugh unit (P-value 0.044; 77 vs 84) was observed in laying hens fed a low protein diet (CP $13 \%$ vs $16 \%$ ) in hot weather at 42 to 55 weeks of age (Torki et al., 2017). Surprisingly, the reduction in egg weight was not significant, but egg mass reduced from $58 \%$ to $52 \%$ in comparison to the control group. Feeding the low protein diet was associated with a significant decline in the intake of crude protein (14.4 vs $17.8 \mathrm{~g} /$ day), valine (792 vs $948 \mathrm{mg} /$ day), and arginine (955 vs $1123 \mathrm{mg} /$ day) (Torki et al., 2017). It was suggested that the low intake of valine affected the albumen synthesis in laying hens. In our study, the lowest intake of crude protein (15.2 $\mathrm{g} /$ day), valine ( $817 \mathrm{mg} /$ day) and arginine ( $983 \mathrm{mg} /$ day) was observed in the laying hens fed the $12.0 \%$ CP diet which was still higher than the value in the study of Torki et al. (2017).

In the present study, the breaking strength of the eggs was lower when laying hens fed the reduced CP diets (14.7 to $12.0 \% \mathrm{CP})$ in comparison to the control diet $(16.1 \% \mathrm{CP})$, while the effect on shell content and shell thickness were not significant. The drop in specific gravity of eggs due to consuming a reduced-cp diet ( $4 \%$ unit lower CP) has been observed which could be related to the alterations in the protein matrix of the eggshell and the proteinous eggshell membranes (reviewed by Shim et al., 2013; Scheideler et al., 2005). The interaction between the organic and the mineral components of the eggshell determine the eggshell strength. Assessing the ultrastructural changes in the eggshell in the case of low protein diets in the laying hens could provide further explanation about the reason for the drop in the breaking strength.

Moisture content is a major determinant of ammonia production in excreta. The nitrogen content of manure includes $\mathrm{N}$ in uric acid, bacterial protein, urea, ammonia, and endogenous nitrogen. In our study, manure moisture and nitrogen content declined gradually by reducing the crude protein content of diets (Table 10). As expected, the stepwise reduction in the crude protein content of the diets reduced the nitrogen intake and subsequently the nitrogen excretion (Figure 8 ), but the ammonium- $\mathrm{N}$ of the manure was not affected (Table 10). Figures 13 and 14 show a strong relationship between crude protein intake and the manure dry matter and nitrogen content, respectively. However, it did not affect the ammonia content of manure. Like our study, Roberts et al. (2006) observed a reduction in nitrogen excretion but not the ammonia excretion in laying hens fed a low protein diet. The authors suggested that the imbalance in amino acids intake due to a low protein diet could impair protein metabolism which resulted in an impaired laying performance (Roberts et al., 2006). In a recent study, reducing the crude protein content of the diet (17.2 vs $13.5 \% \mathrm{CP}$ ) in laying hens between weeks 20 to 39 was associated with a drop in excreta moisture and nitrogen (Dao et al., 2021). 


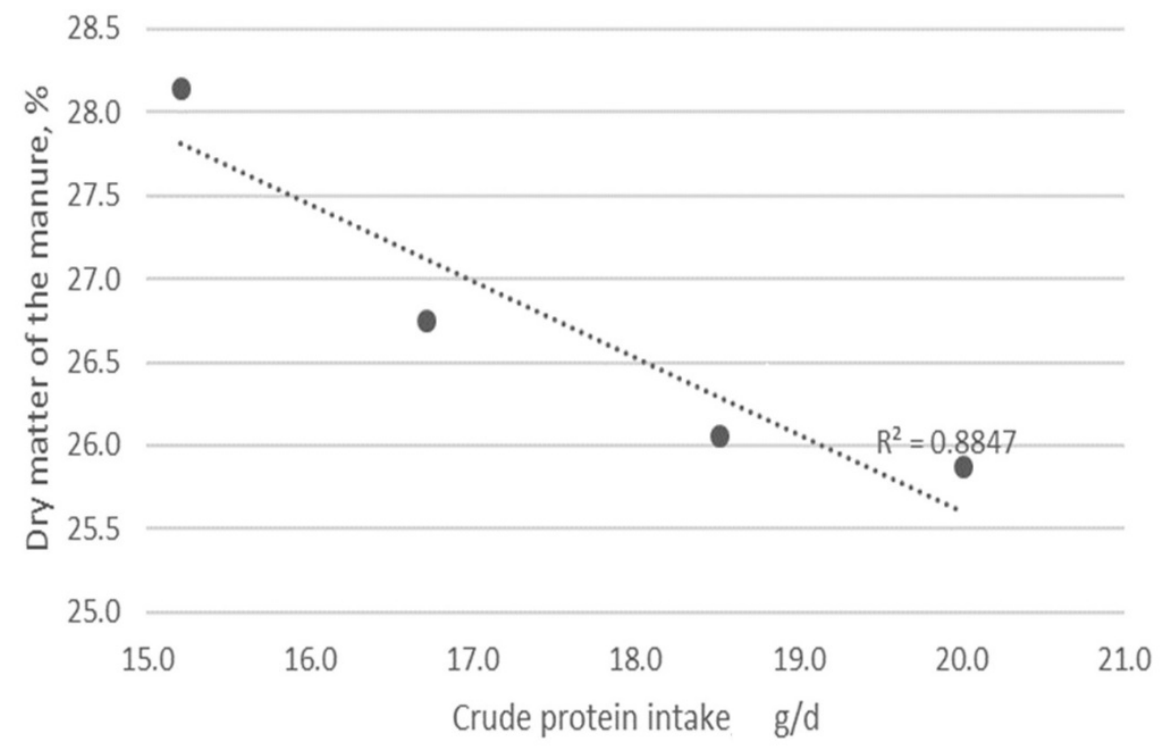

Figure 13 Correlation between the crude protein intake on the dry matter content of the manure of laying hens from 39 - 51 weeks of age.

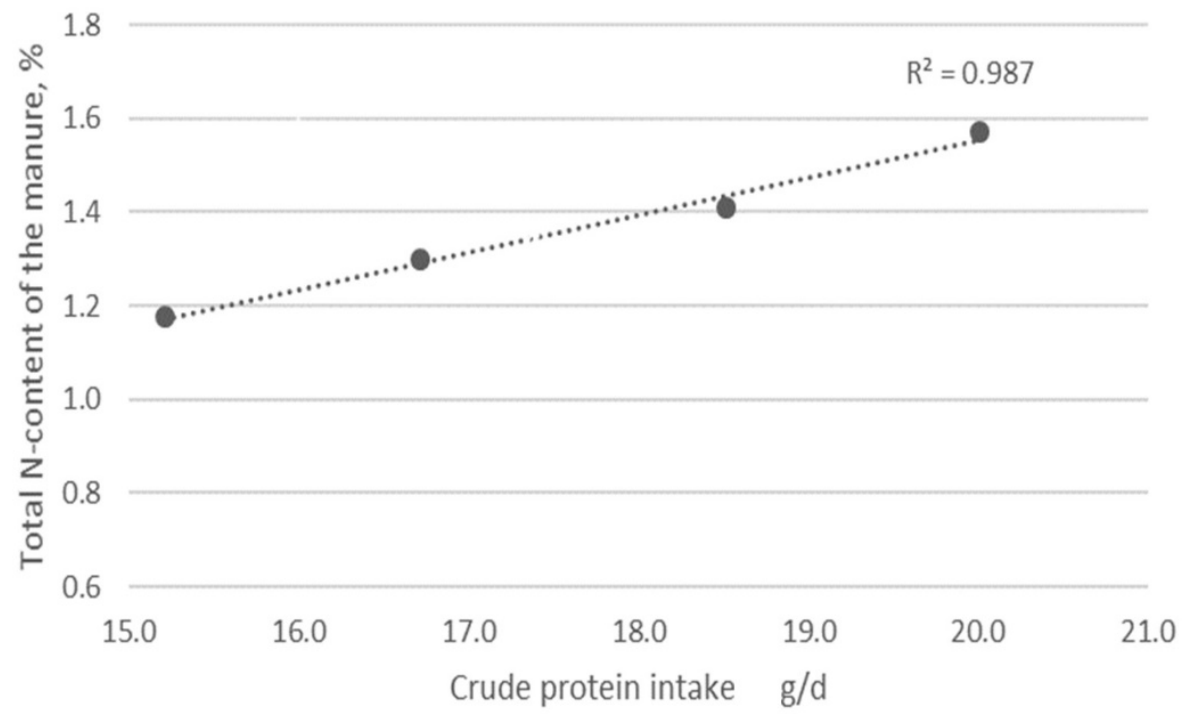

Figure 14 Correlation between the crude protein intake and the total nitrogen content of the manure of laying hens from 39 - 51 weeks of age.

Despite the lower SBM content in the low protein diets, the carbon footprint (CFP) was not lower compared to the control diet. The use of free amino acids is the main reason for the higher CFP. For example the CFP (excl. LUC) for free L-lysine, DL-methionine, L-tryptophan, L-valine, L-arginine, Lisoleucine, L-threonine is $6437,3049,12865,6351,6351,7197$ and $6437 \mathrm{~g} \mathrm{CO}_{2}$-eq/ $\mathrm{kg}$, respectively (FeedPrint database). Marinussen and Kool (2010) describe the environmental impact of the production of free amino acids L-lysine, DL-methionine and L-threonine. For the production of Lthreonine, high quantities of sulphate compounds are required, which significantly contribute to the acidification of the environment and explain the high CFP value of L-threonine.

The current experiment was performed in a trial facility in Vietnam and in battery cages. There is evidence indicating the existence of interaction between the dietary crude protein content and the production system on the production responses of the laying hens. It seems that the housing system affects the protein requirements of the laying hens or their response to the balanced protein diets (Eits et al., 2005). For example, the laying hens in cages reduced the feed intake in response to a decline in the dietary crude protein content from 17.5 to $13 \%$, while the feed intake increased in laying hen in the floor pens (Eits et al., 2005). Viana et al. (2017) stated differences in the responses of the laying 
in cages and floor pens to the crude protein content of diets between the age of 30 to 45 weeks. The interaction between the crude protein content of diets (14 to $18 \% \mathrm{CP}$ ) and the production system was significant in the internal quality of the eggs, i.e. albumen height $(\mathrm{mm})$ and albumen relative weight (\%). In addition, the laying performance and egg quality of laying hens fed a similar diet were significantly different in various housing systems (Englmaierováet al., 2014). Therefore, the outcome of studies in a conventional cage system might not be representative for hens kept in aviary systems as common practice in the EU. Considering the limited amount of knowledge on the effects of low protein diets in laying hens, it is suggested to also perform research on low-protein diets in laying hens in facilities representative for production systems and climate conditions of the laying sector in the EU. 


\section{Conclusion}

From this study, feeding laying hens between $39-51$ week of age diets with $16.1,14.7,13.5$ or $12.0 \%$ crude protein content but similar digestible amino acids contents of the first limiting and free available amino acids, and thereby reducing gradually the soybean meal content from approx. $10 \%$ to $0 \%$, it can be concluded that:

- $\quad$ Reduction of the crude protein content of diet from $16.1 \%$ to $14.7 \%$ with similar content of digestible EAA resulted in a higher laying rate, lower egg weight and fewer Jumbo eggs. Further reduction of crude protein content to $13.5 \%$ and $12.0 \%$ impaired the laying rate, egg weight, egg mass, and feed efficiency

- $\quad$ Reducing the crude protein content of the diet from $16.1 \%$ to $14.7 \%$ did not affect the egg mass, but because of the higher feed intake, the FCR increased.

- Reduction in crude protein content of the diets to $13.7 \%$ and $12.0 \% \mathrm{CP}$ resulted in impaired laying performance.

- $\quad$ The FCR increased with the decreased crude protein contents of the diets.

- The crude protein content of the diets did not affect the mortality rate.

- The crude protein intake decreased linearly with the reduced crude protein content of the diets.

- $\quad$ Egg weight decreased linearly with decreasing crude protein contents of the diets.

- $\quad$ Feeding diets with $12.0 \% \mathrm{CP}$ resulted in a higher \% second-grade eggs. No differences were observed in \% second-grade eggs between the $16.1,14.7$ and $13.5 \%$ diets.

- Albumen in eggs decreased with the decreased crude protein content of the diets.

- Decreasing dietary protein content with similar digestible content of essential amino acids increases the carbon footprint of the diets.

- The calculated feed price increases with a decrease in the crude protein content.

- The calculated economic feed margin is strongly influenced by the availability and price of the protein-rich raw materials and the price of free amino acids. Under the current Dutch market conditions, the feed margins per 100 placed hens of the low-crude protein diets decreased by $€ 12.82$, $€ 56.58$ and $€ 70.08$ respectively for the $14.7,13.5$ and $12.0 \%$ CP-diets.

- Dry matter content of the manure increased linearly with decreasing crude protein content of the diets.

- Total N-content of the manure decreased linearly with decreasing crude protein content of the diets. 


\section{References}

Akbari Moghaddam Kakhki, R., Golian, A., \& Zarghi, H. (2016). Effect of digestible methionine + cystine concentration on performance, egg quality and blood metabolites in laying hens. British Poultry Science, 57(3), 403-414. https://doi.org/10.1080/00071668.2016.1173199.

Kakhki, R. A. M., Golian, A., \& Zarghi, H. (2016). Effect of dietary digestible lysine concentration on performance, egg quality, and blood metabolites in laying hens. Journal of Applied Poultry Research, 25(4), 506-517.

Alagawany, M., \& El-hindawy, M. M. (2020). Influence of low-protein diet with different levels of amino acids on laying hen performance, quality and egg composition. 92, 1-11. https://doi.org/10.1590/00013765202020180230.

Alexandratos, N., and J. Bruinsma. 2012. World agriculture towards 2030/2050: the 2012 revision. ESA Working paper No. 12-03. Rome, FAO.

Apajalahti, J., and K. Vienola, 2016. Interaction between chicken intestinal microbiota and protein digestion. Anim. Feed Sci. Technol. 221:323-330.

Azzam, M. M. M., Dong, X. Y., \& Zou, X. T. (2017a). Effect of dietary threonine on laying performance and intestinal immunity of laying hens fed low-crude-protein diets during the peak production period. 101, 55-66. https://doi.org/10.1111/jpn.12559.

Azzam, M. M. M., Dong, X. Y., \& Zou, X. T. (2017b). Effect of dietary threonine on laying performance and intestinal immunity of laying hens fed low-crude-protein diets during the peak production period. 101, 55-66. https://doi.org/10.1111/jpn.12559.

Hendrix Genetics, 2021. Bovans Brown Product Guide. Cage Production System. https://www.bovans.com/documents/569/Bovans_Brown_CS_cage_English_guide.pdf.

Bunchasak, C \& Silapasorn, T (2005) Effects of adding methionine in low-protein diet on production performance reproductive organs and chemical liver composition of laying hens under tropical conditions, International journal of poultry sience 4 (5), 301-308.

Carvalho, T. S. M., Sousa, L. S., Nogueira, F. A., Vaz, D. P., Saldanha, M. M., Triginelli, M. V., Pinto, M. F. V. S., Baião, N. C., \& Lara, L. J. C. (2018). Digestible methionine+cysteine in the diet of commercial layers and its influence on the performance, quality, and amino acid profile of eggs and economic evaluation. Poultry Science, 97(6), 2044-2052. https://doi.org/10.3382/ps/pey036.

CVB. 2018. Tabellenboek Veevoeding 2018. Voedernormen Pluimvee en voederwaarden voedermiddelen voor Pluimvee [Livestock feed table 2018. Tables values poultry nutrition and feed values raw materials for Poultry]. CVB-reeks nr. 60. Juli 2018.

Dao, H. T., Sharma, N. K., Bradbury, E. J., \& Swick, R. A. (2021). Response of laying hens to l-arginine, Icitrulline and guanidinoacetic acid supplementation in reduced protein diet. Animal Nutrition Volume 7, Issue 2, June 2021, Pages 460-471.

Eits, R. M., R. P. Kwakkel, B. G. E. Reindsen, T. Zandstra and A. A. Maatman, 2005. Effect of housing system on balanced protein requirements in laying hens. In 15 th EUROPEAN SYMPOSIUM ON POULTRY NUTRITION.

Englmaierová, M., Tůmová, E., Charvátová, V., \& Skřivan, M. (2014). Effects of laying hens housing system on laying performance, egg quality characteristics, and egg microbial contamination. Yeast, 15(10).

European Commission, Commission Regulation (EC) No. 152/2009 of 27 January 2009 laying down the methods of sampling and analysis for the official control of feed establishes the sampling method and the methods of analysis of feed for control purposes. Off J Eur Union L54: 177 (2009).

EU, 2017. https://ec.europa.eu/agriculture/market-observatory/crops/oilseeds-protein-crops/balancesheets_en.

Euractiv, 2011. Meps want to end 'protein deficit' for eu livestock.

Evonik. 2010. Total Amino Acid Contents in Feed - Method Oxidation and Hydrolysis. AMINODat 4.0. Evonik Industries, Evonik Degussa GmbH, Hanau-Wolfgang, Germany.

FAO, 2006. World agriculture: Towards 2030/2050. Global Perspective Studies Unit. Food and Agriculture Organization of the United Nations. Rome, June 2006.

FAO, 2009. Global agriculture towards 2050. High Level Expert Forum - How to Feed the World in 2050. Rome, 12-13 October 2009.

FAO, 2017. The future of food and agriculture - Trends and challenges. Rome.

Han, Y., Suzuki, H.C., Parson, M., Baker, D.H., 1992. Amino acid fortification of a low-protein corn and soybean meal diet for chicks. Poult. Sci. 71, 1168-1178.

He, W., Li, P., \& Wu, G. (2021). Amino acid nutrition and metabolism in chickens. Amino Acids in Nutrition and Health: Amino Acids in the Nutrition of Companion, Zoo and Farm Animals, 1285, 109-131. 
Ji, F., Fu, S. Y., Ren, B., Wu, S. G., Zhang, H. J., Yue, H. Y., Gao, J., Helmbrecht, A., \& Qi, G. H. (2014). Evaluation of amino-acid supplemented diets varying in protein levels for laying hens. Journal of Applied Poultry Research, 23(3), 384-392. https://doi.org/10.3382/japr.2013-00831.

Keshavarz, K., Austic, R.E., 2004. The use of low-protein, low-phosphorus, amino acid- and phytasesupplemented diets on laying hen performance and nitrogen and phosphorus excretion. Poult. Sci. 83, 75-83.

Kumari, K. N. R., Chandra, K. R., \& Kumar, D. S. (2016). Effect of protein levels in diet on production and emissions in WHL layer. Adv. Anim. and Vet. sci, 4(7), 357-362.

KWIN-V, 2020-2021. Handboek Kwantitatieve Informatie Veehouderij 2020-2021.

Macelline, S. P., Toghyani, M., Chrystal, P. V., Selle, P. H., \& Liu, S. Y. (2021). Amino acid requirements for laying hens: A comprehensive review. Poultry Science, 101036. https://doi.org/10.1016/j.psj.2021.101036.

Marinussen, M and A. Kool, 2010. Environmental impacts of synthetic amino acid production. Blonk Blonk Milieu Advies report, 23 December 2010.

Mousavi, S. N., Khalaji, S., Ghasemi-Jirdehi, A., \& Foroudi, F. (2013). Investigation on the effects of dietary protein reduction with constant ratio of digestible sulfur amino acids and threonine to lysine on performance, egg quality and protein retention in two strains of laying hens. Italian Journal of Animal Science, 12(2), 9-15. https://doi.org/10.4081/ijas.2013.e2.

Novak, C., Yakout, H. M., \& Scheideler, S. E. (2006). The effect of dietary protein level and total sulfur amino acid:lysine ratio on egg production parameters and egg yield in Hy-Line W-98 hens. Poultry Science, 85(12), 2195-2206. https://doi.org/10.1093/ps/85.12.2195.

Palliyeguru, M.W.C.D., S.P. Rose, and A.M. Mackenzie, 2010. Effect of dietary protein concentrates on the incidence of subclinical necrotic enteritis and growth performance of broiler chickens. Poult Sci, 89 (2010), pp. 34-43.

Parenteau, I.A., Stevenson, M., Kiarie, E.G., 2020. Egg production and quality responses to increasing isoleucine supplementation in Shaver white hens fed a low crude protein corn-soybean meal diet fortified with synthetic amino acids between 20 and 46 weeks of age. Poult. Sci. 99, 1444-1453.

Qaisrani, S.N., M.M. van Krimpen, R.P. Kwakkel, M.W.A. Verstegen, and W.H. Hendriks, 2015. Dietary factors affecting hindgut protein fermentation in broilers: A review. Worlds Poult. Sci. J. 71(1):139160.

Rao, S. V. R., Ravindran, V., Srilatha, T., Panda, A. K., \& Raju, M. V. L. N. (2011). Effect of dietary concentrations of energy, crude protein, lysine, and methionine on the performance of White Leghorn layers in the tropics. JAPR, 20(4), 528-541. https://doi.org/10.3382/japr.2011-00355.

Roberts, S.A., H. Xin, B.J. Kerr, J.R. Russell and K. Bregendahl, 2007. Effects of dietary fiber and reduced crude protein on ammonia emission from laying-hen manure. Poult. Sci., 86 (2007), pp. 1625-1632.

Rockström, J., W. Steffen, K. Noone, A. Persson, F.S. Chapin, E.F. Lambin, T.M. Lenton, M. Scheffer, C. Folke, H.J. Schellnhuber, B. Nykvist, C.A. De Wit, T. Hughes, S. Van Der Leeuw, H. Rodhe, S. Sörlin, P.K. Snyder, R. Costanza, U. Svedin, M. Falkenmark, L. Karlberg, R.W. Corell, V.J. Fabry, J. Hansen, B. Walker, D. Liverman, K. Richardson, P. Crutzen and J.A. Foley, 2009. A safe operating space for humanity. Nature 461(7263):472-475.

Shim, M. Y., Song, E., Billard, L., Aggrey, S. E., Pesti, G. M., \& Sodsee, P. (2013). Effects of balanced dietary protein levels on egg production and egg quality parameters of individual commercial layers. Poultry Science, 92(10), 2687-2696.

Torki, M., Nasiroleslami, M., \& Ghasemi, H. A. (2017). The effects of different protein levels in laying hens under hot summer conditions. Animal Production Science, 57(5), 927-934. https://doi.org/10.1071/AN15463.

Van Gelder, J.W. and B. Kuepper, 2012. Verdeling van de economische waarde van de mondiale sojateelt. Edited by Profundo. Amsterdam.

Vellinga T.V., Blonk H., Marinussen M., Van Zeist W.J., De Boer I.J.M., 2013. Methodology used in feedprint: a tool quantifying greenhouse gas emissions of feed production and utilization. Version 19.00. Wageningen UR Livestock research, Lelystad, the Netherlands.

Viana, G. D. S. (2017). Responses to reduction on dietary crude protein and suppementation of nonessential nitrogen; dietary essential to no-essential nitrogen optimum ratio for white commercial.

Viana, E. D. F., Stringhini, J. H., Carvalho, F. B. D., Viana, D. M. P., \& Costa, M. A. D. (2017). Effects of crude protein levels on egg quality traits of brown layers raised in two production systems. Revista Brasileira de Zootecnia, 46, 847-855.

VSN International, 2019. Genstat for Windows 19th Edition. VSN International, Hemel Hempstead, UK. Web page: Genstat.co.uk.

Wang, H., Wang, X., Zhao, J., Jiao, H., \& Lin, H. (2020). Low protein diet supplemented with crystalline amino acids suppressing appetite and apo-lipoprotein synthesis in laying hens. Animal Feed Science and Technology, 266(May). https://doi.org/10.1016/j.anifeedsci.2020.114533.

WNF 2011. Http://www.Wnf.Nl/nl/wat_wnf_doet/thema_s/bossen/ontbossing/sojateelt/. 


\section{Appendix 1 Experimental diets $1^{\text {st }}$ batch}

\begin{tabular}{|c|c|c|c|c|c|}
\hline & & \multicolumn{4}{|c|}{37 to 46 weeks } \\
\hline \multicolumn{2}{|c|}{ Treatment } & A & B & C & D \\
\hline \multicolumn{2}{|c|}{ Recipe code } & RP075.00 & RP076.00 & RP077.00 & RP078.00 \\
\hline \multicolumn{6}{|l|}{ RAW MATERIALS } \\
\hline CORN * & $\%$ & 33.65 & & & 41.15 \\
\hline WHEAT * & $\%$ & 33.19 & & & 27.52 \\
\hline WHEAT MIDDLINGS MEAL * & $\%$ & & & & 13.49 \\
\hline SBM $48.5-50 \% C P *$ & $\%$ & 9.55 & & & \\
\hline SFM $35-38 \%$ CP * & $\%$ & 12.50 & & & 3.81 \\
\hline SOYBEAN OIL CRUDE * & $\%$ & 0.69 & & & 0.25 \\
\hline LIMESTONE 0.4-0.8MM MEDIUM & $\%$ & 8.68 & & & 8.74 \\
\hline DICALCIUM PHOSPHATE DIHYDRATE & $\%$ & 0.47 & & & 0.55 \\
\hline SALT VACUUM & $\%$ & 0.23 & & & 0.24 \\
\hline NA BICARBONATE & $\%$ & 0.27 & & & 0.27 \\
\hline XYLANASE & $\%$ & 0.03 & & & 0.03 \\
\hline PHYTASE & $\%$ & 0.03 & & & 0.03 \\
\hline L-LYSINE SULPHATE 55\% & $\%$ & 0.28 & & & 0.76 \\
\hline DL-METHIONINE 99\% & $\%$ & 0.12 & & & 0.27 \\
\hline L-THREONINE 99\% POWDER & $\%$ & 0.01 & & & 0.21 \\
\hline L-TRYPTOPHANE 98\% & $\%$ & & & & 0.06 \\
\hline L-VALINE $20 \%$ LOW CA PX & $\%$ & & & & 1.09 \\
\hline ISOLEUCINE $24.77 \%$ & $\%$ & & & & 1.00 \\
\hline L-ARGININE 98\% & $\%$ & & & & 0.23 \\
\hline CHOLIN CHLORID 60\% & $\%$ & 0.04 & & & 0.04 \\
\hline DH400 LAYERpx $0.20 \%$ VN & $\%$ & 0.20 & & & 0.20 \\
\hline CANTHAXANTHIN 1\% PX & $\%$ & 0.04 & & & 0.04 \\
\hline Biofill yellow & $\%$ & 0.03 & & & 0.03 \\
\hline Diet A & $\%$ & & 65.00 & 35.00 & \\
\hline Diet D & $\%$ & & 35.00 & 65.00 & \\
\hline Total & $\%$ & 100.00 & 100.00 & 100.00 & 100.00 \\
\hline Calculated nutrients & Unit & & & & \\
\hline Crude protein & $\%$ & 16.1 & 14.7 & 13.5 & 12.0 \\
\hline Crude fat B (EEh) & $\%$ & 3.3 & 3.3 & 3.3 & 3.3 \\
\hline Crude fat Xtr (EE) & $\%$ & 2.6 & 2.6 & 2.6 & 2.6 \\
\hline Crude fibre & $\%$ & 4.3 & 4.1 & 4.0 & 3.8 \\
\hline Ash & $\%$ & 12.2 & 12.1 & 12.0 & 11.9 \\
\hline Moisture & $\%$ & 9.9 & 10.0 & 10.0 & 10.1 \\
\hline Starch Amyloglucosidase & $\%$ & 40.7 & 42.2 & 43.5 & 45.1 \\
\hline ME poultry enz & $\mathrm{Kcal} / \mathrm{kg}$ & 2764 & 2764 & 2765 & 2765 \\
\hline ME layer enz & $\mathrm{Kcal} / \mathrm{kg}$ & 2800 & 2800 & 2801 & 2801 \\
\hline ME poultry (WPSA) & $\mathrm{MJ} / \mathrm{kg}$ & 11.1 & 11.1 & 11.1 & 11.1 \\
\hline LYS - Lysin & $\%$ & 0.79 & 0.78 & 0.77 & 0.76 \\
\hline afd LYS po & $\%$ & 0.69 & 0.69 & 0.69 & 0.69 \\
\hline afd MET po & $\%$ & 0.36 & 0.38 & 0.40 & 0.42 \\
\hline afd CYS po & $\%$ & 0.25 & 0.23 & 0.21 & 0.19 \\
\hline afd $M+C$ po & $\%$ & 0.61 & 0.61 & 0.61 & 0.61 \\
\hline afd THR po & $\%$ & 0.48 & 0.48 & 0.48 & 0.48 \\
\hline afd TRP po & $\%$ & 0.16 & 0.16 & 0.16 & 0.16 \\
\hline afd ILE po & $\%$ & 0.55 & 0.55 & 0.55 & 0.55 \\
\hline afd ARG po & $\%$ & 0.92 & 0.86 & 0.81 & 0.75 \\
\hline afd VAL po & $\%$ & 0.64 & 0.63 & 0.62 & 0.61 \\
\hline afd LEU po & $\%$ & 1.08 & 0.96 & 0.85 & 0.73 \\
\hline afd GLU po & $\%$ & 3.1 & 2.74 & 2.45 & 2.07 \\
\hline afd PHE po & $\%$ & 0.68 & 0.58 & 0.5 & 0.41 \\
\hline afd TYR po & $\%$ & 0.44 & 0.38 & 0.33 & 0.27 \\
\hline afd HIS po & $\%$ & 0.36 & 0.31 & 0.27 & 0.23 \\
\hline afd ALA po & $\%$ & 0.61 & 0.55 & 0.49 & 0.44 \\
\hline afd ASP po & $\%$ & 1.16 & 0.95 & 0.75 & 0.56 \\
\hline afd PRO po & $\%$ & 0.93 & 0.86 & 0.81 & 0.71 \\
\hline afd GLY po & $\%$ & 0.59 & 0.52 & 0.44 & 0.37 \\
\hline afd SER po & $\%$ & 0.66 & 0.57 & 0.5 & 0.41 \\
\hline afd $\mathrm{G}+\mathrm{S}$ po & $\%$ & 1.25 & 1.09 & 0.94 & 0.78 \\
\hline Starch Ewers & $\%$ & 42 & 43 & 45 & 46 \\
\hline Sugar & $\%$ & 2.7 & 2.6 & 2.4 & 2.3 \\
\hline $\mathrm{C} 16: 0+\mathrm{C} 18: 0$ & $\%$ & 0.4 & 0.4 & 0.4 & 0.4 \\
\hline C18:2 - Linoleic & $\%$ & 1.5 & 1.5 & 1.5 & 1.5 \\
\hline Calcium & $\%$ & 3.70 & 3.70 & 3.70 & 3.70 \\
\hline Phosphor tot & $\%$ & 0.46 & 0.47 & 0.47 & 0.48 \\
\hline dP poultry & $\%$ & 0.30 & 0.30 & 0.30 & 0.30 \\
\hline Sodium & $\%$ & 0.18 & 0.18 & 0.18 & 0.18 \\
\hline Chlorine & $\%$ & 0.20 & 0.20 & 0.20 & 0.20 \\
\hline Potassium & $\%$ & 0.63 & 0.58 & 0.55 & 0.50 \\
\hline $\mathrm{dEB}$ & meq & 182 & 171 & 161 & 150 \\
\hline Choline $(-\mathrm{OH})$ tot & $\mathrm{mg} / \mathrm{kg}$ & 1184 & 1081 & 993 & 891 \\
\hline Vit D3 eq sum add & $\mathrm{IU} / \mathrm{kg}$ & 3023 & 3023 & 3023 & 3023 \\
\hline Vit $A$ add (3a672a) & $\mathrm{IU} / \mathrm{kg}$ & 10076 & 10076 & 10076 & 10076 \\
\hline Vit D3 add (3a671) & $\mathrm{IU} / \mathrm{kg}$ & 3023 & 3023 & 3023 & 3023 \\
\hline Vit $E$ add $(3 a 700)$ & $\mathrm{mg} / \mathrm{kg}$ & 30 & 30 & 30 & 30 \\
\hline Xanthophyll sum & $\mathrm{mg} / \mathrm{kg}$ & 12.7 & 12.6 & 12.6 & 12.5 \\
\hline Canthaxanthin (2a161g) & $\mathrm{mg} / \mathrm{kg}$ & 4.0 & 4.0 & 4.0 & 4.0 \\
\hline Phytase equivalents & $\mathrm{sFU} / \mathrm{kg}$ & 300 & 300 & 300 & 300 \\
\hline
\end{tabular}

* analysed on AMINONir 


\section{Appendix 2 Experimental diets $2^{\text {nd }}$ batch}

\begin{tabular}{|c|c|c|c|c|c|}
\hline & \multicolumn{5}{|c|}{46 to 52 weeks } \\
\hline & & A & B & c & D \\
\hline & & RP075 & RP076 & RP077 & RP078 \\
\hline \multicolumn{6}{|l|}{ Raw materials } \\
\hline CORN* & $\%$ & 30.56 & & & 40.35 \\
\hline WHEAT* & $\%$ & 36.76 & & & 27.93 \\
\hline WHEAT MIDDLINGS PELLET** & $\%$ & & & & 15.56 \\
\hline SBM 48.5-50\%CP* & $\%$ & 11.06 & & & \\
\hline SFM $30-35 \% C P *$ & $\%$ & 10.97 & & & 2.03 \\
\hline SOYBEAN OIL CRUDE* & $\%$ & 0.53 & & & 0.25 \\
\hline LIMESTONE COARSE & $\%$ & 8.47 & & & 8.74 \\
\hline DICALCIUM PHOSPHATE DIHYDRATE & $\%$ & 0.40 & & & 0.54 \\
\hline SALT VACUUM & $\%$ & 0.23 & & & 0.23 \\
\hline NA BICARBONATE & $\%$ & 0.27 & & & 0.28 \\
\hline XYLANASE & $\%$ & 0.03 & & & 0.03 \\
\hline PHYTASE & $\%$ & 0.03 & & & 0.03 \\
\hline L-LYSINE SULPHATE 55\% & $\%$ & 0.25 & & & 0.77 \\
\hline DL-METHIONINE 99\% & $\%$ & 0.12 & & & 0.27 \\
\hline L-THREONINE 99\% POWDER & $\%$ & 0.02 & & & 0.22 \\
\hline L-TRYPTOPHANE 98\% & $\%$ & & & & 0.06 \\
\hline L-VALINE $20 \%$ LOW CA PX & $\%$ & & & & 1.13 \\
\hline ISOLEUCINE $24.77 \%$ & $\%$ & & & & 1.04 \\
\hline L-ARGININE 98\% & $\%$ & & & & 0.25 \\
\hline CHOLIN CHLORID 60\% & $\%$ & 0.04 & & & 0.04 \\
\hline DH400 LAYERpx0.20\%VN & $\%$ & 0.20 & & & 0.20 \\
\hline CANTHAXANTHIN $1 \%$ PX & $\%$ & 0.04 & & & 0.04 \\
\hline Biofill yellow & $\%$ & 0.04 & & & 0.03 \\
\hline F4F trial control diet $\mathrm{A}$ & $\%$ & & 65.00 & 35.00 & \\
\hline $\mathrm{F} 4 \mathrm{~F}$ trial control diet $\mathrm{D}$ & $\%$ & & 35.00 & 65.00 & \\
\hline Total & $\%$ & 100.00 & 100.0 & 100.0 & 100.00 \\
\hline \multicolumn{6}{|l|}{ Calculated nutrients } \\
\hline Crude protein & $\%$ & 16.1 & 14.7 & 13.5 & 12.0 \\
\hline Crude fat B (EEh) & $\%$ & 3.1 & 3.2 & 3.2 & 3.2 \\
\hline Crude fat Xtr (EE) & $\%$ & 2.4 & 2.5 & 2.5 & 2.6 \\
\hline Crude fibre & $\%$ & 4.5 & 4.3 & 4.0 & 3.8 \\
\hline Ash & $\%$ & 12.0 & 12.0 & 12.0 & 12.0 \\
\hline Moisture & $\%$ & 9.7 & 9.8 & 9.9 & 10.0 \\
\hline Starch Amyloglucosidase & $\%$ & 40.8 & 42.2 & 43.5 & 44.9 \\
\hline ME poultry enz & $\mathrm{Kcal} / \mathrm{kg}$ & 2757 & 2759 & 2761 & 2763 \\
\hline ME layer enz & Kcal/kg & 2791 & 2793 & 2796 & 2798 \\
\hline ME poultry (WPSA) & $\mathrm{MJ} / \mathrm{kg}$ & 11.1 & 11.1 & 11.1 & 11.1 \\
\hline LYS - Lysin & $\%$ & 0.79 & 0.78 & 0.77 & 0.76 \\
\hline afd LYS po & $\%$ & 0.69 & 0.69 & 0.69 & 0.69 \\
\hline afd MET po & $\%$ & 0.36 & 0.38 & 0.40 & 0.42 \\
\hline afd CYS po & $\%$ & 0.25 & 0.23 & 0.21 & 0.19 \\
\hline afd $M+C$ po & $\%$ & 0.61 & 0.61 & 0.61 & 0.61 \\
\hline afd THR po & $\%$ & 0.48 & 0.48 & 0.48 & 0.48 \\
\hline afd TRP po & $\%$ & 0.16 & 0.16 & 0.16 & 0.16 \\
\hline afd ILE po & $\%$ & 0.55 & 0.55 & 0.55 & 0.55 \\
\hline afd ARG po & $\%$ & 0.90 & 0.85 & 0.81 & 0.75 \\
\hline afd VAL po & $\%$ & 0.64 & 0.63 & 0.62 & 0.61 \\
\hline afd LEU po & $\%$ & 1.09 & 0.96 & 0.85 & 0.73 \\
\hline afd GLU po & $\%$ & 3.17 & 2.79 & 2.47 & 2.08 \\
\hline afd PHE po & $\%$ & 0.68 & 0.58 & 0.5 & 0.4 \\
\hline afd TYR po & $\%$ & 0.45 & 0.39 & 0.33 & 0.27 \\
\hline afd HIS po & $\%$ & 0.36 & 0.31 & 0.28 & 0.23 \\
\hline afd ALA po & $\%$ & 0.61 & 0.55 & 0.49 & 0.43 \\
\hline afd ASP po & $\%$ & 1.16 & 0.94 & 0.75 & 0.53 \\
\hline afd PRO po & $\%$ & 0.97 & 0.89 & 0.82 & 0.73 \\
\hline afd GLY po & $\%$ & 0.58 & 0.5 & 0.44 & 0.36 \\
\hline afd SER po & $\%$ & 0.67 & 0.58 & 0.5 & 0.41 \\
\hline afd $\mathrm{G}+\mathrm{S}$ po & $\%$ & 1.25 & 1.08 & 0.94 & 0.77 \\
\hline Starch Ewers & $\%$ & 42 & 44 & 45 & 46 \\
\hline Sugar & $\%$ & 2.9 & 2.7 & 2.5 & 2.3 \\
\hline C16:0+C18:0 & $\%$ & 0.4 & 0.4 & 0.4 & 0.4 \\
\hline C18:2 - Linoleic & $\%$ & 1.4 & 1.4 & 1.5 & 1.5 \\
\hline Calcium & $\%$ & 3.4 & 3.5 & 3.5 & 3.5 \\
\hline Phosphor tot & $\%$ & 0.48 & 0.48 & 0.48 & 0.48 \\
\hline dP poultry & $\%$ & 0.30 & 0.30 & 0.30 & 0.30 \\
\hline Sodium & $\%$ & 0.18 & 0.18 & 0.18 & 0.18 \\
\hline Chlorine & $\%$ & 0.20 & 0.20 & 0.20 & 0.20 \\
\hline Potassium & $\%$ & 0.69 & 0.63 & 0.57 & 0.51 \\
\hline dEB & meq & 198 & 182 & 169 & 153 \\
\hline Choline $(-\mathrm{OH})$ tot & $\mathrm{mg} / \mathrm{kg}$ & 1181 & 1072 & 979 & 870 \\
\hline Vit D3 eq sum add & $\mathrm{IU} / \mathrm{kg}$ & 3023 & 3023 & 3023 & 3023 \\
\hline Vit $A$ add (3a672a) & $\mathrm{IU} / \mathrm{kg}$ & 10076 & 10076 & 10076 & 10076 \\
\hline Vit D3 add (3a671) & $\mathrm{IU} / \mathrm{kg}$ & 3023 & 3023 & 3023 & 3023 \\
\hline Vit E add (3a700) & $\mathrm{mg} / \mathrm{kg}$ & 30 & 30 & 30 & 30 \\
\hline Xanthophyll sum & $\mathrm{mg} / \mathrm{kg}$ & 13 & 13 & 13 & 13 \\
\hline Canthaxanthin (2a161g) & $\mathrm{mg} / \mathrm{kg}$ & 4 & 4 & 4 & 4 \\
\hline Phytase equivalents & $\mathrm{sFU} / \mathrm{kg}$ & 300 & 300 & 300 & 300 \\
\hline
\end{tabular}




\section{Appendix 3 Weekly performance parameters}
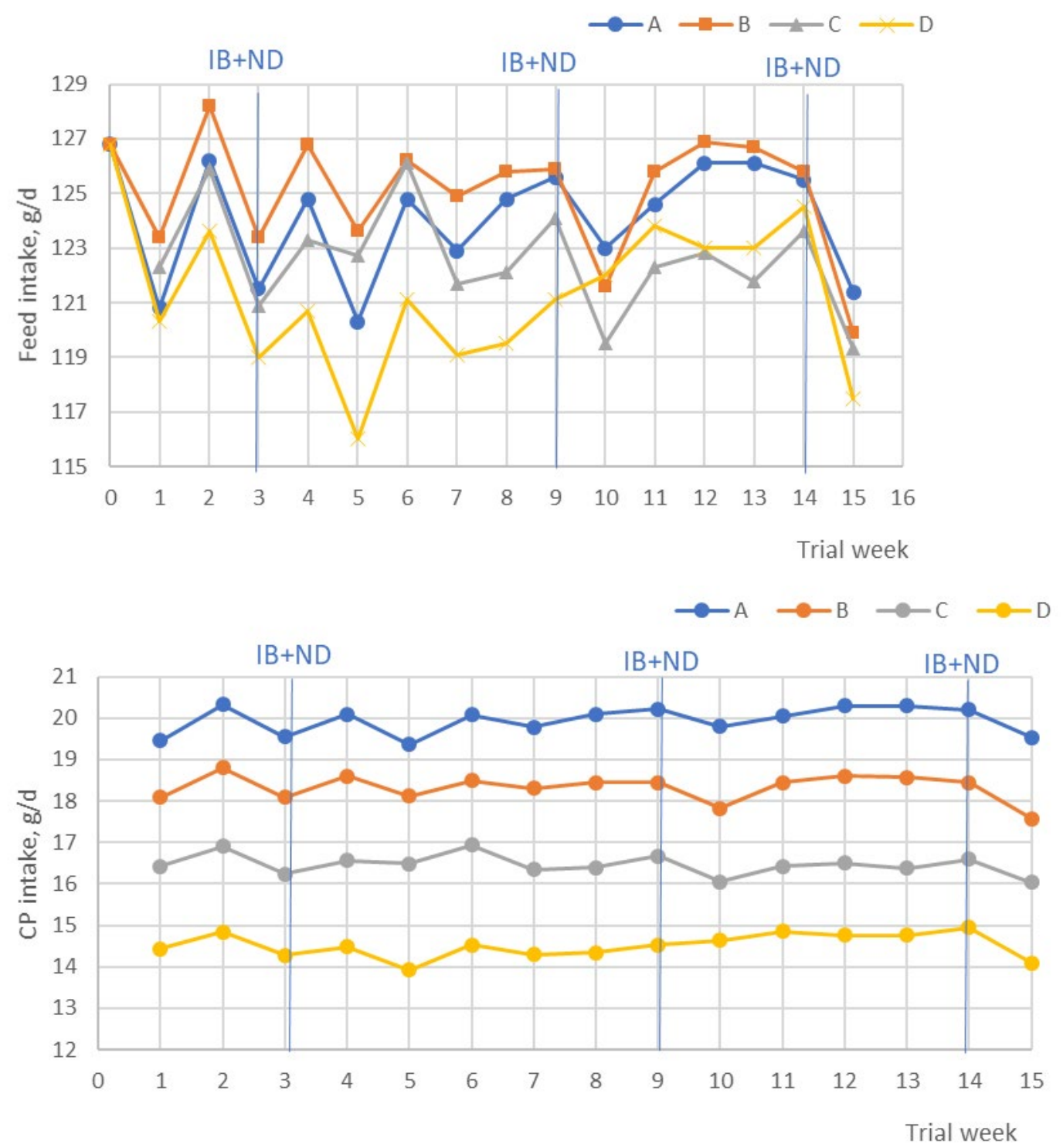

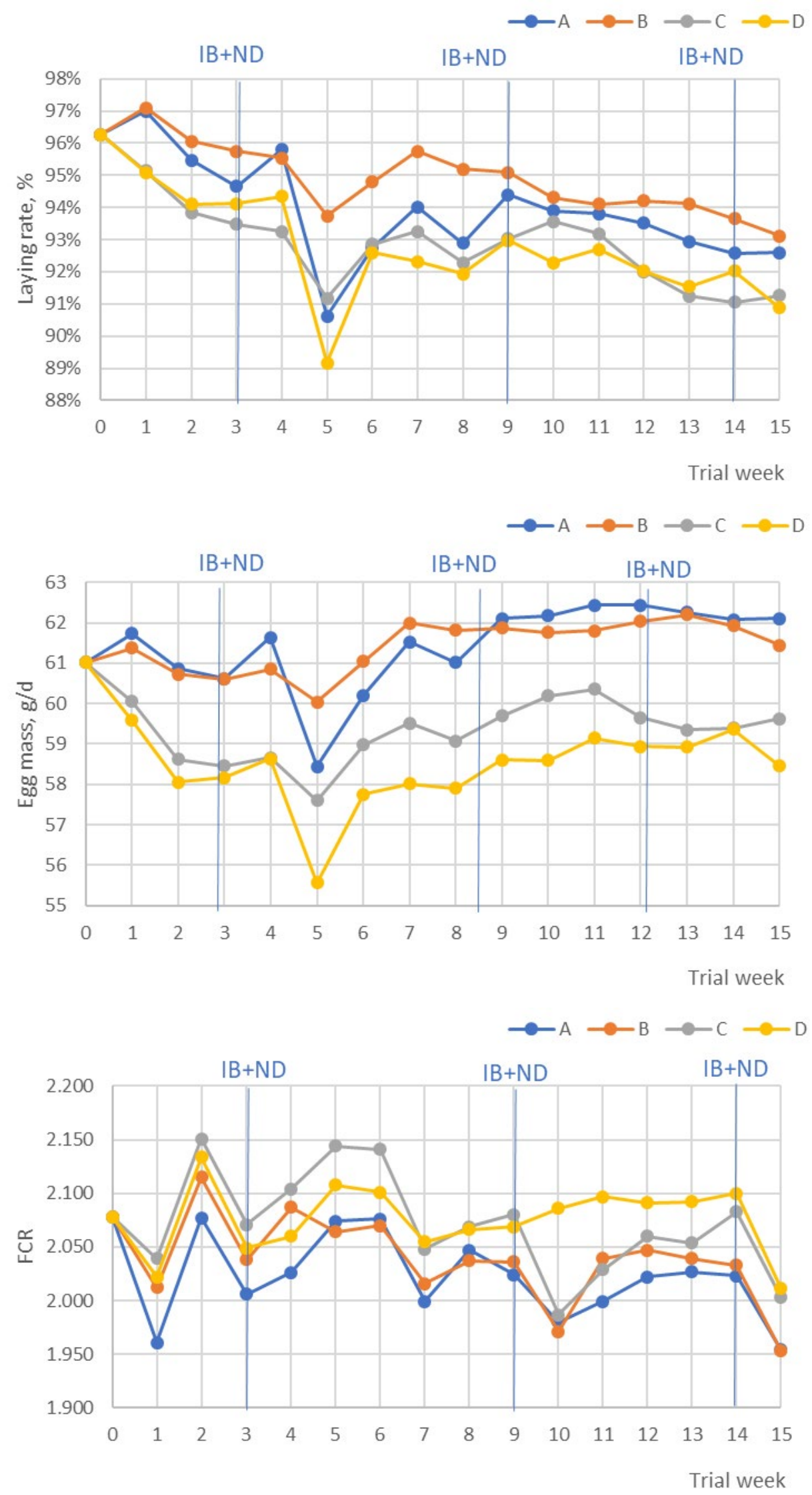


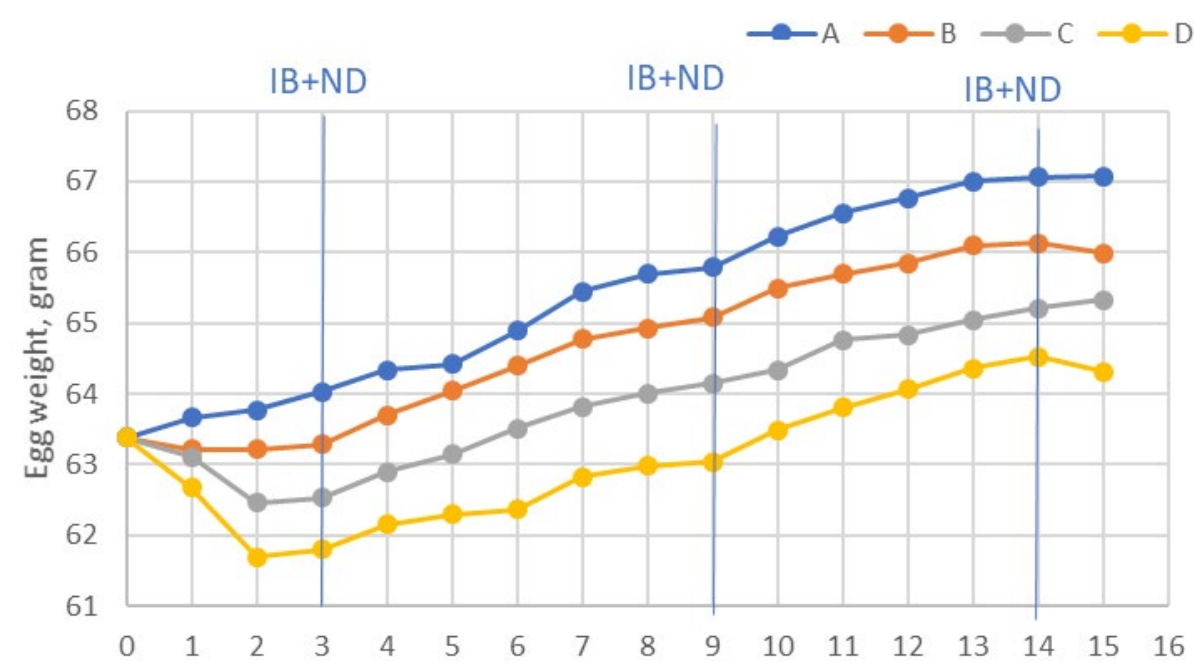

Trial week
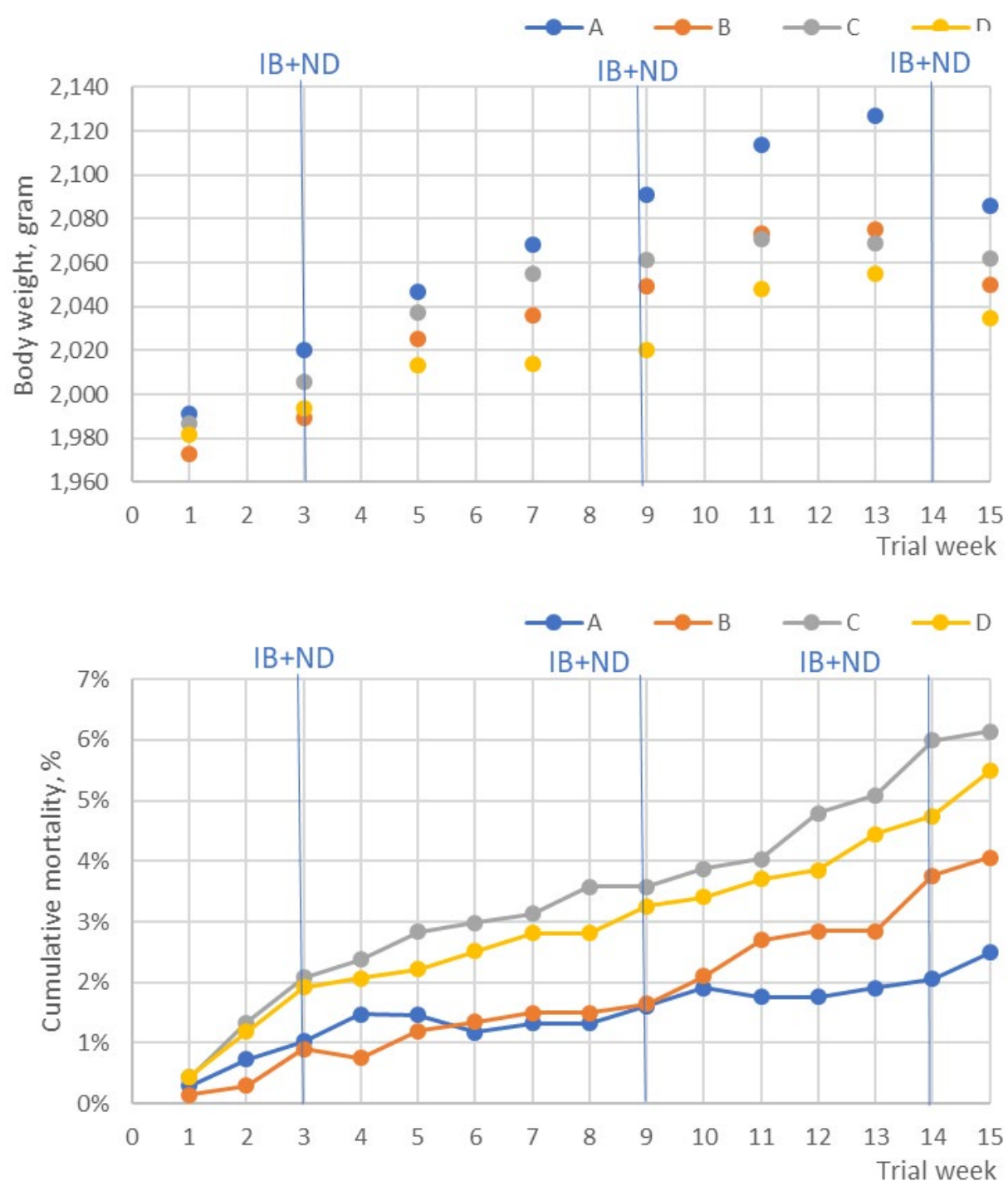


\section{Appendix 4 Carbon footprint diets}

\begin{tabular}{|c|c|c|c|c|c|c|c|c|c|}
\hline \multirow[t]{2}{*}{ Batch 1} & \multirow{2}{*}{$\begin{array}{c}A \\
(16.1 \% \\
C P) \\
\text { RP075 }\end{array}$} & \multirow{2}{*}{$\begin{array}{c}\text { B } \\
(14.7 \% \\
\text { CP }) \\
\text { RP076 }\end{array}$} & \multirow{2}{*}{$\begin{array}{c}C \\
(13.5 \% \\
C P) \\
\text { RP077 }\end{array}$} & \multirow{2}{*}{$\begin{array}{c}\text { D } \\
(12.0 \% \\
\text { CP) } \\
\text { RP078 }\end{array}$} & \multirow{2}{*}{$\begin{array}{l}\text { CFP } \\
\text { (excl. } \\
\text { LUC) }\end{array}$} & \multicolumn{4}{|c|}{ CFP (excl. LUC) } \\
\hline & & & & & & RP075 & RP076 & RP077 & RP078 \\
\hline CORN & 33.65 & 36.27 & 38.52 & 41.15 & 489 & 165 & 177 & 188 & 201 \\
\hline WHEAT & 33.19 & 31.21 & 29.51 & 27.52 & 439 & 146 & 137 & 130 & 121 \\
\hline WHEAT MIDDLINGS & 0.00 & 4.72 & 8.77 & 13.49 & 270 & 0 & 13 & 24 & 36 \\
\hline SBM $48.5-50 \% C P$ & 9.55 & 6.20 & 3.34 & 0.00 & 602 & 57 & 37 & 20 & 0 \\
\hline SFM $35-38 \% C P$ & 12.50 & 9.46 & 6.85 & 3.81 & 404 & 51 & 38 & 28 & 15 \\
\hline SOY BEAN OIL & 0.69 & 0.53 & 0.40 & 0.25 & 1630 & 11 & 9 & 7 & 4 \\
\hline LIMESTONES & 8.68 & 8.70 & 8.72 & 8.74 & 519 & 45 & 45 & 45 & 45 \\
\hline DICALCIUMPHOSPHATE & 0.47 & 0.50 & 0.52 & 0.55 & 575 & 3 & 3 & 3 & 3 \\
\hline SALT & 0.23 & 0.24 & 0.24 & 0.24 & 180 & 0 & 0 & 0 & 0 \\
\hline NA BICARBONATE & 0.27 & 0.27 & 0.27 & 0.27 & 490 & 1 & 1 & 1 & 1 \\
\hline XYLANASE enzyme & 0.03 & 0.03 & 0.03 & 0.03 & 1174 & 0 & 0 & 0 & 0 \\
\hline AXTRA PHY 10000 TPT & 0.03 & 0.03 & 0.03 & 0.03 & 1894 & 0 & 0 & 0 & 0 \\
\hline L-LYSINE SULPHATE $55 \%$ & 0.28 & 0.45 & 0.59 & 0.76 & 6437 & 18 & 29 & 38 & 49 \\
\hline DL-METHIONINE 99\% & 0.12 & 0.17 & 0.21 & 0.27 & 3050 & 4 & 5 & 7 & 8 \\
\hline L-THREONINE 99\% & 0.01 & 0.08 & 0.14 & 0.21 & 6437 & 1 & 5 & 9 & 13 \\
\hline L-TRYPTOPHANE 98\% & 0.00 & 0.02 & 0.04 & 0.06 & 12865 & 0 & 3 & 5 & 8 \\
\hline L-VALINE 20\% & 0.00 & 0.38 & 0.71 & 1.09 & 6351 & 0 & 24 & 45 & 69 \\
\hline test ingredient 1 Isoleucine & 0.00 & 0.35 & 0.65 & 1.00 & 7197 & 0 & 25 & 47 & 72 \\
\hline test ingredient 2 L-ARGININE $98 \%$ & 0.00 & 0.08 & 0.15 & 0.23 & 6351 & 0 & 5 & 10 & 15 \\
\hline CHOLIN CHLORID 60\% & 0.04 & 0.04 & 0.04 & 0.04 & 4159 & 2 & 2 & 2 & 2 \\
\hline LAYERpx0.20\%VN & 0.20 & 0.20 & 0.20 & 0.20 & 1174 & 2 & 2 & 2 & 2 \\
\hline CANTHAXANTHIN $1 \%$ PX & 0.04 & 0.04 & 0.04 & 0.04 & 1174 & 0 & 0 & 0 & 0 \\
\hline \multirow[t]{2}{*}{ Yellow colorant } & 0.03 & 0.03 & 0.03 & 0.03 & 1174 & 0 & 0 & 0 & 0 \\
\hline & & & & & & 507 & 563 & 612 & 668 \\
\hline
\end{tabular}

\begin{tabular}{|c|c|c|c|c|c|c|c|c|c|}
\hline \multirow[t]{2}{*}{ Batch 2} & \multirow{2}{*}{$\begin{array}{c}A \\
(16.1 \% \\
\text { CP) } \\
\text { RP075 }\end{array}$} & \multirow{2}{*}{$\begin{array}{c}\text { B } \\
(14.7 \% \\
\text { CP) } \\
\text { RP076 }\end{array}$} & \multirow{2}{*}{$\begin{array}{c}C \\
(13.5 \% \\
\text { CP) } \\
\text { RP077 }\end{array}$} & \multirow{2}{*}{$\begin{array}{c}D \\
(12.0 \% \\
\text { CP) } \\
\text { RP078 }\end{array}$} & \multirow{2}{*}{$\begin{array}{l}\text { CFP } \\
\text { (excl. } \\
\text { LUC) }\end{array}$} & \multicolumn{4}{|c|}{ CFP (excl. LUC) } \\
\hline & & & & & & RP075 & RP076 & RP077 & RP078 \\
\hline CORN & 30.56 & 33.98 & 36.92 & 40.35 & 489 & 149 & 166 & 181 & 197 \\
\hline WHEAT & 36.76 & 33.67 & 31.02 & 27.93 & 439 & 161 & 148 & 136 & 123 \\
\hline WHEAT MIDDLINGS & 0.00 & 5.44 & 10.11 & 15.56 & 270 & 0 & 15 & 27 & 42 \\
\hline SBM $48.5-50 \% C P$ & 11.06 & 7.19 & 3.87 & 0.00 & 602 & 67 & 43 & 23 & 0 \\
\hline SFM $35-38 \% C P$ & 10.97 & 7.84 & 5.16 & 2.03 & 404 & 44 & 32 & 21 & 8 \\
\hline SOY BEAN OIL & 0.53 & 0.43 & 0.35 & 0.25 & 1630 & 9 & 7 & 6 & 4 \\
\hline LIMESTONES & 8.47 & 8.56 & 8.64 & 8.74 & 519 & 44 & 44 & 45 & 45 \\
\hline DICALCIUMPHOSPHATE & 0.40 & 0.45 & 0.49 & 0.54 & 575 & 2 & 3 & 3 & 3 \\
\hline SALT & 0.23 & 0.23 & 0.23 & 0.23 & 180 & 0 & 0 & 0 & 0 \\
\hline NA BICARBONATE & 0.27 & 0.27 & 0.28 & 0.28 & 490 & 1 & 1 & 1 & 1 \\
\hline XYLANASE enzyme & 0.03 & 0.03 & 0.03 & 0.03 & 1174 & 0 & 0 & 0 & 0 \\
\hline AXTRA PHY 10000 TPT & 0.03 & 0.03 & 0.03 & 0.03 & 1894 & 0 & 0 & 0 & 0 \\
\hline L-LYSINE SULPHATE 55\% & 0.25 & 0.43 & 0.59 & 0.77 & 6437 & 16 & 28 & 38 & 49 \\
\hline DL-METHIONINE 99\% & 0.12 & 0.17 & 0.22 & 0.27 & 3050 & 4 & 5 & 7 & 8 \\
\hline L-THREONINE 99\% & 0.02 & 0.09 & 0.15 & 0.22 & 6437 & 1 & 6 & 9 & 14 \\
\hline L-TRYPTOPHANE 98\% & 0.00 & 0.02 & 0.04 & 0.06 & 12865 & 0 & 3 & 5 & 8 \\
\hline L-VALINE 20\% & 0.00 & 0.39 & 0.73 & 1.13 & 6351 & 0 & 25 & 47 & 72 \\
\hline test ingredient 1 Isoleucine & 0.00 & 0.37 & 0.68 & 1.04 & 7197 & 0 & 26 & 49 & 75 \\
\hline test ingredient 2 L-ARGININE 98\% & 0.00 & 0.09 & 0.17 & 0.25 & 6351 & 0 & 6 & 10 & 16 \\
\hline CHOLIN CHLORID 60\% & 0.04 & 0.04 & 0.04 & 0.04 & 4159 & 2 & 2 & 2 & 2 \\
\hline LAYERpx0.20\%VN & 0.20 & 0.20 & 0.20 & 0.20 & 1174 & 2 & 2 & 2 & 2 \\
\hline CANTHAXANTHIN 1\% PX & 0.04 & 0.04 & 0.04 & 0.04 & 1174 & 0 & 0 & 0 & 0 \\
\hline \multirow[t]{2}{*}{ Yellow colorant } & 0.04 & 0.03 & 0.03 & 0.03 & 1174 & 0 & 0 & 0 & 0 \\
\hline & & & & & & 505 & 563 & 613 & 672 \\
\hline
\end{tabular}




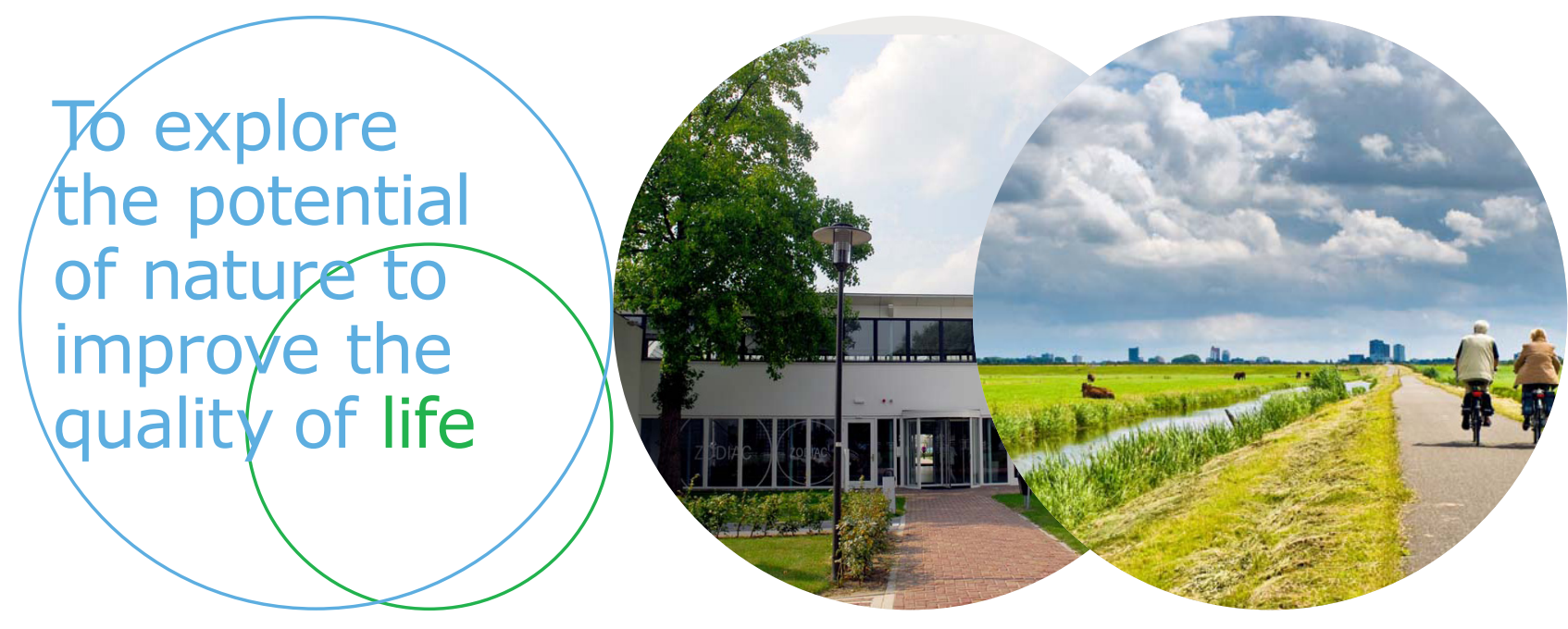

Wageningen Livestock Research P.O. Box 338

6700 AH Wageningen

The Netherlands

$\mathrm{T}+31(0) 317483953$

E info.livestockresearch@wur.nl

www.wur.nl/livestock-research

Wageningen Livestock Research creates science based solutions for a sustainable and profitable livestock sector. Together with our clients, we integrate scientific knowledge and practical experience to develop livestock concepts for future generations.

Wageningen Livestock Research is part of Wageningen University \& Research. Together we work on the mission: 'To explore the potential of nature to improve the quality of life'. A staff of 6,500 and 10,000 students from over 100 countries are working worldwide in the domain of healthy food and living environment for governments and the business community-at-large. The strength of Wageningen University \& Research lies in its ability to join the forces of specialised research institutes and the university. It also lies in the combined efforts of the various fields of natural and social sciences. This union of expertise leads to scientific breakthroughs that can quickly be put into practice and be incorporated into education. This is the Wageningen Approach. 